\title{
Geochemical provenance of sediments from the northern East China Sea document a gradual migration of the Asian Monsoon belt over the past 400,000 years
}

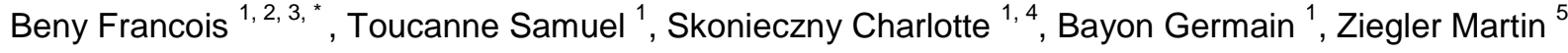

${ }^{1}$ IFREMER, Laboratoire Géodynamique et Enregistrement Sédimentaire, ZI de La Pointe Du Diable, CS 10070, 29280 Plouzané, France

${ }^{2}$ Univ. Lille, CNRS, Univ. Littoral Côte D’Opale, UMR 8187, LOG, Laboratoire D'Océanologie et de Géosciences, F 59000 Lille, France

${ }^{3}$ VU University Amsterdam, Department of Earth Sciences, Faculty of Science, De Boelelaan 1085, 1081 HV Amsterdam, The Netherlands

${ }^{4}$ Laboratoire GEOsciences Paris-Sud (GEOPS), UMR CNRS 8148, Université de Paris-Sud, Université Paris-Saclay, 91405 Orsay Cedex, France

${ }^{5}$ Utrecht University, Heidelberglaan 2 3584CS Utrecht, The Netherlands

*Corresponding author : François Beny, email address : francois.beny@univ-lille1.fr

\begin{abstract}
:
The reconstruction of the long-term evolution of the East Asian Monsoon remains controversial. In this study, we aim to give a new outlook on this evolution by studying a $400 \mathrm{kyr}$ long sediment record (U1429) from the northern East China Sea recovered during IODP Expedition 346. Neodymium isotopic ratios and rare earth element concentrations of different grain-size fractions reveal significant provenance changes of the sediments in the East China Sea between East Asian continental sources (mainly Yellow River) and sediment contributions from the Japanese Archipelago. These provenance changes are interpreted as the direct impact of sea level changes, due to the reorganization of East Asian river mouth locations and ocean circulation on the East China Sea shelf, and latitudinal shifts of the intertropical convergence zone (ITCZ) from the interior of Asia to the western North Pacific Ocean. Our data reveal the dominance of winter and summer monsoons during glacial and interglacial periods, respectively, except for glacial MIS 6d ( 150-180 ka) during which unexpected summer monsoon dominated conditions prevailed. Finally, our data suggests a possible strengthening of the interglacial summer monsoon rainfalls over the East Asian continent and Japan throughout the past $400 \mathrm{kyr}$, and between MIS 11 and MIS 5 in particular. This could result from a gradual northward migration of the ITCZ.
\end{abstract}




\section{Highlights}

- REE and Nd isotopes of detrital sediment in the northern East China Sea. ITCZ and sea level fluctuations as a primary forcings for sediment source changes. Dominance of the winter/summer monsoon during glacials/interglacials, respectively. Gradual northward shift of the monsoon belt over the last $400 \mathrm{kyr}$.

Keywords : Monsoon, Eastern Asia, East China sea, Quaternary, Radiogenic isotopes, Neodymium, Rare earth elements 


\section{Introduction}

The distribution of rainfall associated with the global monsoon system is tightly linked to the seasonal latitudinal shifts of the intertropical convergence zone (ITCZ), with high precipitation occurring in East Asia during the boreal summer when the ITCZ is located in the northern hemisphere. Our understanding of past East Asian monsoon dynamics is mainly based on reconstructions from continental archives such as speleothems (Wang et al., 2001; Yuan et al., 2004; Dykosky et al., 2005; Wang et al., 2008; Jo et al., 2014; Cheng et al., 2016), loess sequences (Zhisheng et al., 2001; Sun et al., 2006; Yang and Ding, 2008; Meng et al., 2018) and lacustrine sedimentary records (An et al., 2000; Xiao et al., 2004). These studies provide substantial information on the evolution of the East Asian Monsoon system during the Pleistocene, documenting palaeoclimatic records exhibiting glacial-interglacial (loess records) and/or precessional cyclicities (speleothems).

Marine sediments deposited in the East China Sea, in addition to South China Sea sedimentary records (e.g. Wang et al., 1999; Liu et al., 2003), represent suitable archives for investigating the evolution of the East Asian monsoon over glacial-interglacial timescales (e.g. Chang et al., 2009). The East China Sea serves as a sink for the particulate load delivered by the Yangtze (Changjiang) and Yellow (Huanghe) rivers systems, two of the world's longest rivers. Their drainage areas are strongly influenced by monsoon-dominated climate. Sedimentary archives from the Yangtze and Yellow rivers deltas (Yi et al., 2003; Yi and Saito, 2001; Chen et al., 2005; Xiao et al., 2006), as well as from the Okinawa Trough in the northern East China Sea (Sun et al., 2005; Yu et al., 2009; Kubota et al., 2010; Zhao et al., 2018), have been used to reconstruct the East Asian Monsoon signal back to the last glacial maximum $\sim 20-30 \mathrm{ka}$. In these studies, the evolution of the East Asian monsoon was reconstructed from the flux of East Asian river detrital sediments to nearby oceanic areas (Saito et al., 2001; Liu et al., 2007; Hu et al., 2012). In particular, these fluxes were inferred 
through the tracking of the chemical and mineralogical signatures of Yangtze and/or Yellow rivers sediments as far as the Okinawa Trough (Diekmann et al., 2008; Dou et al., 2010; Dou et al., 2012; Xu et al., 2014; Li et al., 2015; Zhao et al., 2017, 2018). However, there are a lack of sedimentary archives recording the response of East Asian river basins to monsoonrelated climatic changes over several interglacial-glacial cycles. Such records are necessary to understand the long-term variability of East Asian monsoon and its response to orbital forcing. In this study, we aim at filling this gap by studying a marine sediment record (U1429; Fig. 1) covering the last $400 \mathrm{kyr}$ and recovered in the northern Okinawa Trough during the Integrated Ocean Drilling Program (IODP) Expedition 346 (Expedition 346 Scientists, 2014). The approach developed in this study is based on a detailed geochemical investigation of the detrital fraction of the U1429 Site sediments by combining major and rare earth element (REE) concentrations and neodymium $(\mathrm{Nd})$ isotopic ratios. These proxies provide valuable information on sediment provenance. In the context of monsoon-dominated climates, these proxies allow us to reconstruct the response of river systems to past hydroclimate changes. Because decoupling of REE and Nd isotopes may occur between different grain-size fractions during hydrodynamic sorting and weathering processes, with possible implications for their use as provenance proxies (e.g.Meyer et al., 2011; Garçon and Chauvel, 2014; Bayon et al., 2015), we analyse several targeted grain-size fractions.

\section{The East Asian sediment-routing systems}

\subsection{Geography, geology and climatology of the East Asian drainage systems}

The Yangtze River $\left(6400 \mathrm{~km}\right.$ in length; drainage area of $\left.1807 \times 10^{3} \mathrm{~km}^{2}\right)$ and the Yellow River ( $5450 \mathrm{~km}$ in length; drainage area of $752 \times 10^{3} \mathrm{~km}^{2}$ ) are the two major drainage 
systems in East Asia (Fig. 1). Both rivers start in the northeast Tibetan Plateau (Qinghai Province) at about $5000 \mathrm{~m}$ elevation and flow eastward, delivering a total sediment flux of about $1,600 \times 10^{6}$ t/yr to the East China Sea (Milliman and Syviski, 1992; Saito et al., 2001). Although a significant part of this flux $(\sim 60 \%)$ is derived from the Yellow river, the Chinese Loess Plateau in particular, the Yangtze river was likely the main source of sediment to the East China Sea prior to the onset of extensive agricultural activity in the Loess Plateau about 2,200 years ago (Milliman et al., 1987). The contribution from Taiwan, estimated from 260 to $380 \times 10^{6} \mathrm{t} / \mathrm{yr}$ for the whole island, is minor in comparison, and only the Lanyang River's sediment ( $\left.\sim 8 \times 10^{6} \mathrm{t} / \mathrm{yr}\right)$ directly entered the southern Okinawa Trough (Huh et al., 2006).

The geological formations of the Yangtze and Yellow river basins provide a diverse array of detrital sediments. The Yangtze river basin hosts volcanic, plutonic, metamorphic, and various Paleozoic to Quaternary sedimentary rocks (Yang et al, 2007). Metamorphic rocks, Cenozoic sedimentary formations, and Quaternary loess characterize the Yellow river Basin (Lin et al. 2001, and references therein).

The alternation of winter (dry, cold) and summer (warm, humid) monsoon-dominated periods characterizes past East Asian monsoons, with their intensities changing in concert with Greenland temperatures and orbitally-driven changes in northern hemisphere summer insolation (Wang et al., 2001; Wang et al., 2008). These hydrological fluctuations influence the dispersal of mineral dust. At present, dust deposits of the Loess Plateau are mainly derived from the Gobi desert (Fig. 1) and other regions of Northwest China. During glacial periods, however, mineral dust from the Loess Plateau likely originated from the Qaidam Basin and the northern Tibetan Plateau (Chen et al., 2007; Sun et al., 2008; Kapp et al., 2011; Pullen et al., 2011). The alternation of these dust sources as principal contributors to the Loess Plateau sediment during the Quaternary is linked to latitudinal shifts in the northern hemisphere Subtropical Jet Stream wind system, which in turn reflects changes in the position of the 
115 ITCZ. For example, southward migrations of the subtropical jet stream during glacial periods

116 led to enhanced aridity in Central Asia by decreasing the intensity of the East Asian summer 117 monsoon (Nagashima et al., 2011; Pullen et al., 2011).

\subsection{Offshore dispersal of the East Asian sediment}

The East China Sea is a wide (up to $600 \mathrm{~km}$ ) and shallow $(<120-200 \mathrm{~m}$ ) epicontinental shelf. It is considered to be a typical example of a river-dominated ocean margin (Liu et al., 2007). Along the shelf, the sediments delivered by the Yangtze and Yellow rivers are dispersed by the northward flowing Kuroshio Current, the Taiwan Warm Current, and the Yellow Sea Warm Current, the latter flowing counter-clockwise in the East China and Yellow

125 Seas (Beardsley et al., 1985; Liu et al., 2007; Fig. 1). Consequently, the sediments discharged from the East Asian rivers are first transported southward along the inner shelf before being routed towards the northeast (Beardsley et al., 1985; Chang et al., 2009). This sediment

128 dispersal pattern was markedly different during glacial intervals when sea level was lower by $129 \sim 120$ meters and shallow areas were subaerially exposed (Waelbroeck et al., 2002; Grant et al., 2014). At these times, the East China Sea shelf area was reduced and both the Yangtze and Yellow river mouths were much closer to the Okinawa Trough (Fig. 1). The Yellow river mouth was located east of Cheju Island and fed the Goto Submarine Canyon (Danjo Basin, northern Okinawa Trough), located south of the Goto Islands (southwestern Japan) (Owaine

134 et al., 2011; Xu et al., 2014). By contrast, the Yangtze River likely fed the middle part of the

135 Okinawa Trough during glacial lowstands (e.g. Ujiié and Ujiié, 1999; Xu et al., 2014).

136 Furthermore, the Kuroshio Current was strongly reduced in strength (e.g. Kao et al., 2006)

137 and shifted eastward out of the Okinawa Trough (Ujiié and Ujiié, 1999; Jian et al., 2000; Ujiié 138 et al., 2003) during glacial periods. Such changes may explain why the Kuroshio Current only 
139 impacts sedimentation in the East China Sea during interglacial periods (e.g. Jian et al., 2000;

140 Diekmann et al., 2008).

\section{Material and methods}

\section{$143 \quad 3.1 \quad$ The Danjo Basin hemipelagic succession}

144 This study is based on core samples collected during the IODP Expedition 346 (July $14529^{\text {th }}-$ September $\left.27^{\text {th }}, 2013\right)$ at Site U1429 $\left(31^{\circ} 37.04^{\prime}\right.$ N $, 128^{\circ} 59.85^{\prime} E, 732 \mathrm{~m}$ water depth; Fig.

146 1). Site U1429 is located in the northernmost part of the East China Sea, more precisely in the 147 southern part of the Okinawa Trough's Danjo Basin. Three holes were drilled at Site U1429 148 using the advanced piston corer (APC) system to a maximum depth of $188.3 \mathrm{~m}$ below the 149 seafloor (mbsf). Hole-to-hole correlations (constrained by the shipboard natural gamma ray, 150 color reflectance, and magnetic susceptibility data) enabled the construction of a spliced 151 section to $188 \mathrm{~m}$ composite depth (or CCSF-D, Core Composite depth below Sea Floor). The 152 tephrostratigraphy for U1429, along with the $\delta^{18} \mathrm{O}$ of benthic foraminifers (Fig. 2), reveals 153 that the sedimentary sequence, mainly composed of olive-gray to greenish gray calcareous 154 nannofossil ooze and calcareous nannofossil-rich clay (Expedition 346 Scientists, 2014), 155 extends from the Middle Pleistocene ( $\sim 385 \mathrm{ka}$, MIS 11/10 transition) to the Holocene 156 (Sagawa et al., 2018). Glacial-interglacial variability is constrained together with the $\delta^{18} \mathrm{O}$, 157 with the high-resolution $(1 \mathrm{~cm}) \mathrm{Ca} / \mathrm{Fe}$ data from XRF scans acquired at the Earth Science 158 Department at ETH Zürich (Fig. 2). Sedimentation rates average $\sim 85$ and $\sim 23 \mathrm{~cm}$ during 159 glacials and interglacials, respectively. Two centimeters of sediment were sampled every $\sim 4$ $160 \mathrm{~m}$ for a temporal resolution of $\sim 8 \mathrm{kyr}$. We avoided sampling visible tephra layers. 


\subsection{Methods}

163

164

165

166

A series of experiments was set up to identify the main phases (i.e. biogenic, detritic, volcanic) of the bulk sediment in order to determine the most relevant grain-size fractions for reconstructing past terrigenous sediment sources at Site U1429. For this purpose, 8 representative samples were selected from glacial and interglacial sediment intervals, including a glass-rich Holocene tephra. Based on scanning electron microscopy (SEM), optical microscopy, and laser grain-size measurements, we elected to focus on the fine sediments $(<63 \mu \mathrm{m})$, subdividing the samples into four grain-size fractions: the clay fraction $(<2 \mu \mathrm{m})$, the cohesive silty fraction $(2-30 \mu \mathrm{m})$, the non-cohesive silty fraction $(30-63 \mu \mathrm{m})$, and the bulk fine fraction $(0-63 \mu \mathrm{m})$. We measured REE concentrations and $\mathrm{Nd}$ isotope ratios for each fraction (Fig. 3).

\subsection{Sample preparation}

The bulk fine fraction of the samples $(n=42$, including the 8 representative samples discussed above) were wet-sieved at $63 \mu \mathrm{m}$ and $30 \mu \mathrm{m}$. The clay and cohesive silt fractions ( $<2$ and 2-30 $\mu \mathrm{m}$ ) were separated by centrifugation (see Bayon et al., 2015 for details). The bulk fine fraction $(0-63 \mu \mathrm{m})$ was preserved only for 4 of the representative samples because of the limited amount of sediments. After drying $\left(30^{\circ} \mathrm{C}\right)$, a sequential extraction procedure was used to remove the non-terrigenous components with the exception of biogenic opal. Biogenic carbonates were removed using a mixture of $10 \%$ acetic acid and acetate sodium $(4<\mathrm{pH}<5), \mathrm{Fe}-\mathrm{Mn}$ oxyhydroxide phases using hydroxylamine hydrochloride solution, and organic compounds using 5\% $\mathrm{H}_{2} \mathrm{O}_{2}$ (Bayon et al., 2002). Note that the REE content in marine opal is quite low compared to corresponding detrital fractions ( $\sim 3 \mathrm{ppm}$ for $\mathrm{Nd}$; Grousset et al., 1998), so that removal of opal is generally not required prior to $\mathrm{Nd}$ isotopic analyses of 
terrigenous sediments (Bayon et al., 2002). Nevertheless, as a precaution, we focused on samples with limited biogenic silica content (i.e. less than $\sim 10 \%$ ).

\subsection{Analytical procedure}

3.4.1 Rare earth and other trace elements

For trace elements and $\mathrm{Nd}$ isotopic analyses, $\sim 100 \mathrm{mg}$ of dry sediment powder was digested by alkaline fusion (Bayon et al., 2009). This method ensures complete dissolution of sediment samples, including those containing resistant refractory minerals such as zircons, and gives typical blank contributions below the $0.1 \%$ level for all elements. Trace element concentrations were measured by ICP-MS (Quad X-Series 2; Thermo Scientific) at the Pôle Spectrométrie Océan, Brest (France). REE abundances were corrected for polyatomic oxide and hydroxide interferences and calculated using the Tm addition method (Barrat et al., 1996; Bayon et al., 2009). The accuracy of our data was assessed by analysing rock standards and the precision on all measurements was better than $4 \%$, in agreement with the typical precision of alkaline fusion methods (better than 5\%; Bayon et al., 2009).

\subsubsection{Neodymium isotopes}

Nd was separated using a two-column ion exchange method with AG50W-X8 and Ln resins, as described in the supplementary materials of Bayon et al. (2012). Typical blank levels during the alkaline fusion procedure were generally below $1 \mathrm{ng}$ for $\mathrm{Nd}$ and thus negligible $(<0.1 \%)$ given the large sample sizes of the sediments (between $80-100 \mathrm{mg}$ ). Isotopic measurements were performed by sample bracketing at the Pôle Spectrométrie Océan (Brest) using a Thermo Scientific Neptune multi-collector ICP-MS. Mass bias corrections on $\mathrm{Nd}$ were made with the exponential law, using ${ }^{146} \mathrm{Nd} /{ }^{144} \mathrm{Nd}=0.7219$. Mass-bias corrected 
values for ${ }^{143} \mathrm{Nd} /{ }^{144} \mathrm{Nd}$ were normalized to a JNdi-1 value of ${ }^{143} \mathrm{Nd} /{ }^{144} \mathrm{Nd}=0.512115$ (Tanaka

211 et al., 2000). The average ${ }^{143} \mathrm{Nd} /{ }^{144} \mathrm{Nd}$ value of JNdi-1 during our measurements was

$2120.512117 \pm 0.000007$. Analyses of the La Jolla standard solution during the course of this

213 study gave ${ }^{143} \mathrm{Nd} /{ }^{144} \mathrm{Nd}$ of $0.511860 \pm 0.000009(2 \mathrm{SD}, \mathrm{n}=4)$, agreeing well with the certified

214 value $(0.511858 \pm 0.000007$; Lugmair et al., 1983) and corresponding to an external

215 reproducibility of $\sim \pm 0.17 \varepsilon(2 \mathrm{SD})$. Neodymium isotope data are reported using the epsilon

216 notation, which corresponds to the deviation of measured ${ }^{143} \mathrm{Nd} /{ }^{144} \mathrm{Nd}$ ratios relative to the

217 Chondritic Uniform Reservoir (CHUR) value of 0.512638 (Jacobsen and Wasserburg, 1980).

\section{Results and discussion}

\subsection{Deciphering the provenance information recorded by the different grain-size}

\section{1 fractions}

The microscopic observations of the bulk test samples led to the identification of distinct components in the sediments, including biogenic and terrigenous silica, biogenic carbonate clasts (mainly foraminifers), clays, and oxides. In addition, many samples displayed variable amounts of volcanic shards $(5-300 \mu \mathrm{m}$; grain-size mode around $40 \mu \mathrm{m})$ and biogenic silica $(10-70 \mu \mathrm{m}$; grain-size mode around $15 \mu \mathrm{m})$, mainly concentrated in size-fractions coarser than $10 \mu \mathrm{m}$. SEM observations also reveal the presence of heavy minerals such as monazite, titanite, barite, and zircons, each preferentially concentrated in the $<10 \mu \mathrm{m}$ fraction. Evidence of aeolian transport is not observed for the test samples.

231 in Table 1. Nd concentrations range between 13 and $29 \mathrm{ppm}$ and do not vary as a function of 232 the grain size. Two different types of WRAS-normalized REE patterns (World River Average 233 Silt - WRAS; Bayon et al., 2015) are distinguishable between the size-fractions. While most 
234 of the fractions display relatively flat shale-normalized patterns, the $30-63 \mu \mathrm{m}$ interglacial 235 sediments are characterized by depletion of the light rare earth elements (LREE) and 236 enrichment of the heavy rare earth elements (HREE) (Fig. 4). Similarly, while the 0-2, 2-30, 237 and $0-63 \mu \mathrm{m}$ fractions are characterized by $\varepsilon_{\mathrm{Nd}}$ values ranging from -10.6 to -7.1 , the 30 $23863 \mu \mathrm{m}$ fraction displays greater $\mathrm{Nd}$ isotopic variability and more radiogenic values (reaching 239 2.7; Fig. 3). The different size fractions of the glass-rich Holocene sample have more 240 radiogenic $\mathrm{Nd}$ isotopic compositions with $\varepsilon_{\mathrm{Nd}}$ values ranging from -3.9 to +1.6 .

Our results indicate that the different sediment grain-size fractions have distinct REE and $\varepsilon_{\mathrm{Nd}}$ signatures, hence suggesting that they host distinct sediment sources. During the warm interglacial periods, the non-cohesive silt fraction $(30-63 \mu \mathrm{m})$ is characterized by radiogenic $\square_{\mathrm{Nd}}$ values (i.e., $-2.3<\varepsilon_{\mathrm{Nd}}<+1.7$ ) and HREE enrichment relative to LREE, suggesting a volcanic origin. The volcanic provenance is also supported by the results obtained for the Holocene tephra level (Kikai-Akahoya, $7.2 \mathrm{ka}$ ) originating from Kyushu island (see Sagawa et al., 2018 and references therein) (Figs 3 and 4). These geochemical characteristics for the coarse-grained sediments are similar to those of river sediments from

249 Southern Japan $\left(\varepsilon_{\mathrm{Nd}}=+2\right.$; Fig. 3), representing the dominant radiogenic source in the area. 250 By contrast, the finest $(<2 \mu \mathrm{m} ; 2-30 \mu \mathrm{m})$ and coarsest $(30-63 \mu \mathrm{m})$ fractions from glacial 251 periods are both characterized by low radiogenic $\square_{\mathrm{Nd}}$ values (i.e., $-10.6<\varepsilon_{\mathrm{Nd}}<-6.3$ ) and a 252 WRAS-like REE composition (Figs 3 and 4). These $\mathrm{Nd}$ isotopic compositions suggest 253 mixing between mainland rivers (e.g. Korean, Chinese rivers; $\varepsilon_{\mathrm{Nd}}<-10$ ) and southern 254 Japanese rivers $\left(\varepsilon_{\mathrm{Nd}}>-4\right)$. Although the Japanese contribution is not clearly expressed in the 255 REE compositions, our results are independently supported by clay mineral and $\mathrm{Sr}-\mathrm{Nd}-\mathrm{Pb}$ 256 isotopic data for the last glacial-interglacial transition (Zhao et al., 2017, 2018). Indeed, they 257 reveal that the finest size fractions at Site U1429 are predominantly sourced from the Yellow 258 River and southern Japanese rivers, with limited contributions from the Yangtze. 
Aeolian contributions at Site U1429 are difficult to quantify. While the Loess Plateau 260 contributes significantly $(\sim 90 \%)$ to the modern Yellow river sediment load, our geochemical 261 tracers cannot distinguish whether a sediment grain was transported by atmospheric (i.e., 262 dust) or fluvial processes (Yang et al., 2002). Nevertheless, the present-day atmospheric flux 263 of dust in the East China Sea $\left(26 \mathrm{~g} \cdot \mathrm{m}^{-2} \cdot \mathrm{yr}^{-1}\right)$, comparable to late Quaternary records of aeolian 264 dust accumulation (Gao et al., 1997), composes only $\sim 4-6 \%$ of the terrigenous sediment flux 265 at U1429 during the last glacial (up to $60 \mathrm{~g} \cdot \mathrm{cm}^{-2} \cdot \mathrm{kyr}^{-1}$; Zhao et al., 2017). Moreover, the 266 impact of aeolian transport on our geochemical investigations is restricted to the clay-sized fraction because the mean grain-size of dust particles reaching the modern China Sea is $\sim 1.9 \mu \mathrm{m}$ (Gao et al., 1997). This is supported by the absence of aeolian morphologies for the U1429 silt grains observed through SEM. We thus conclude that the impact of dust inputs at Site U1429, although not negligible, is low over the studied period. Likewise, we conclude that Taiwanese sediments are not present at Site U1429 in appreciable quantities due to a lack of LREE enrichment (Diekmann et al., 2008; Dou et al., 2010, 2012; Zhao et al., 2017, 2018). The lack of Taiwanese sediment transport to the Danjo Basin is probably due to the outflow 274 of the Kuroshio Current from the Okinawa Trough south of the Ōsumi archipelago (i.e. 275 Tokara Strait), 300 km south of Site U1429 (e.g. Feng et al., 2000; Fig. 1). 277 cohesive silt $(30-63 \mu \mathrm{m})$ fractions to investigate past provenance changes at Site U1429. The 278 clay fraction has minimal contamination from volcanic shards and biogenic silica. This 279 fraction was previously analysed to discern past variations in the discharge of river-borne 280 detrital sediments from the Yellow river and Japanese rivers (Zhao et al., 2017, 2018). The 281 non-cohesive silt fraction will provide insights into the evolution of paleoclimatic conditions 282 in Japan. We excluded samples with large numbers of volcanic shards from the paleoclimatic 
283 reconstruction in order to separate volcanic eruptions from broader changes in regional 284 climate. Throughout the last $400 \mathrm{kyr}, \mathrm{Nd}$ concentrations range between 13 and $29 \mathrm{ppm}$ for the clay fraction, and between 11 and 27 ppm for the non-cohesive silty fraction (Table 2). The $\mathrm{Nd} / \mathrm{Yb}$ ratio, a measure of HREE enrichment, is commonly used to discriminate the provenance of sediments. Shale-normalized $\mathrm{Nd} / \mathrm{Yb}$ ratios $(\mathrm{Nd} / \mathrm{Yb})_{\mathrm{N}}$ close to 1 are typical of 291 the upper continental crust, whereas $(\mathrm{Nd} / \mathrm{Yb})_{\mathrm{N}}$ ratios of less than 1 may indicate the presence 292 of volcanic materials (Bayon et al., 2015). In Site U1429 sediments, the clay fraction is 293 characterized by $(\mathrm{Nd} / \mathrm{Yb})_{\mathrm{N}}$ ratios ranging from 0.83 to 1.15 (Table 2), exhibiting REE 294 patterns without particular enrichment or depletion relative to the average continental 295 sediments. The non-cohesive silt fraction $(30-63 \mu \mathrm{m})$, however, is characterized by a 296 significantly lower $(\mathrm{Nd} / \mathrm{Yb})_{\mathrm{N}}$ ratios from 0.49 to 1.08 (Fig. 2b). These lower values suggest 297 the incorporation of substantial amounts of volcanic sediments from Japan. While the $298(\mathrm{Nd} / \mathrm{Yb})_{\mathrm{N}}$ of the clay fraction remains relatively constant throughout the studied interval, the $299(\mathrm{Nd} / \mathrm{Yb})_{\mathrm{N}}$ ratios of the non-cohesive silts tracks the glacial/interglacial cyclicity, with higher 300 values recorded during glacial intervals (Fig. 2b). 302 period, with most radiogenic values corresponding to the interglacials. While the non303 cohesive silt $\varepsilon_{\mathrm{Nd}}$ values are more variable, with $\varepsilon_{\mathrm{Nd}}$ ranging from -10.3 to +3.4 , the most 304 radiogenic values are also found during the interglacials (Fig. 2a). We also notice a 305 progressive increase in the mean $\varepsilon_{\mathrm{Nd}}$ throughout the last $400 \mathrm{kyr}$. Over the entire interval, this 
rise corresponds to a positive $\varepsilon_{\mathrm{Nd}}$ shift of $1.2 \pm 0.2$ for the clay fraction and $5 \pm 3$ for the noncohesive silt fraction (Fig. 2a).

\subsection{Sediment provenance at Site U1429}

Results from the past $400 \mathrm{kyr}$ are consistent with the recent results of Zhao et al.

$311(2017,2018)$ that suggest two dominant sediment sources at U1429. Both the fine fractions

$312(0-2 \mu \mathrm{m}$ and $2-30 \mu \mathrm{m})$ show unradiogenic $\varepsilon_{\mathrm{Nd}}$ and WRAS-like REE patterns suggesting a

313 Yellow river source $\left(-13.9<\varepsilon_{\mathrm{Nd}}<-9.6 ; \mathrm{Nd} / \mathrm{Yb}\right.$ ratio $\sim$; Figs 2, 5 and 6, Table 3) with

314 minor contributions from southern Japanese rivers $\left(\varepsilon_{\mathrm{Nd}}>-2 ; \mathrm{Nd} / \mathrm{Yb}<<1\right.$; Figs 5 and 6,

315 Table 3). The provenance of the non-cohesive silt fraction $\varepsilon_{\mathrm{Nd}}$ and $(\mathrm{Nd} / \mathrm{Yb})_{\mathrm{N}}$ is less clear.

316 During glacial periods, the combination of their unradiogenic $\varepsilon_{\mathrm{Nd}}$ values, high $(\mathrm{Nd} / \mathrm{Yb})_{\mathrm{N}} \operatorname{ratios}$

317 and WRAS-like REE patterns may indicate a dominant Yellow river provenance, but during 318 interglacials the more radiogenic $\varepsilon_{\mathrm{Nd}}$ compositions, lower $(\mathrm{Nd} / \mathrm{Yb})_{\mathrm{N}}$ ratios, and HREE 319 enrichment suggests an increased contribution of volcanogenic material. These observations 320 imply varying relative contributions from Yellow river (-dominant) and southern Japan (321 dominant) sediment sources to the non-cohesive silt fractions during glacial and interglacial 322 periods, respectively. The $\varepsilon_{\mathrm{Nd}}$ value of -5 represents a threshold for the REE patterns, with 323 samples having $\varepsilon_{\mathrm{Nd}}$ less than -5 being characterized by WRAS-like composition (i.e. upper continental crust) and samples with $\varepsilon_{\mathrm{Nd}}$ greater than -5 more closely reflecting volcanic compositions (Fig. 6).

\subsection{Glacial/Interglacial variations}

During the last $400 \mathrm{kyr}$, the $\varepsilon_{\mathrm{Nd}}$ values of the clay and non-cohesive silts vary in phase with the glacial-interglacial cyclicity (Fig. 2). This variability reflects the fluctuating 
contributions from southern Japanese and Yellow rivers sediments to the northern tip of the

331 Okinawa Trough. As discussed in Section 4.3, the coarser fraction is dominated by the

332 Yellow river during glacial periods and by southern Japanese rivers during interglacial

333 periods. Lowstand conditions and the associated eastward migration of the Yellow River delta

334 towards Site U1429 during glacial intervals (Oiwane et al., 2011) likely explain the increasing

335 contributions of Yellow River sediments to this coarser fraction. Since the Yangtze river 336 mouth has migrated towards the Middle Okinawa Trough during glacials (Ujiié et al., 1991),

337 it did not contribute significantly to glacial sedimentation at Site U1429 (Zhao et al.,2017,

338 2018). Similarly, sea level rise of about 100-130 m (Waelbroeck et al., 2002; Grant et al., 339 2014) involves a westward migration of the Yellow river delta of about $1,000 \mathrm{~km}$ and the

340 appearance of the Yellow Sea warm current onto the East China Sea shelf. The combination

341 of the Yellow river delta migration with the significant change in the regional oceanic

342 circulation likely explains the decreasing contribution of the Yellow River to the non-

343 cohesive silt fraction at glacial-interglacial transitions. In addition, significant inputs of

344 Japanese sources during interglacials could have occurred in response to increasing rainfall

345 over Japan in response to the northward movement of the ITCZ (e.g. Xiao et al. 1999; Jo et 346 al., 2014). For an analogy in terms of modern atmospheric processes, precipitation over Japan

347 is more likely during summer. Enhanced precipitation may have led to an increase in Japanese

348 river basin erosion (Xiao et al., 1999), favouring the transport of sediments to the Danjo

349 basin. Therefore, $\varepsilon_{\mathrm{Nd}}$ changes observed in the non-cohesive silt fraction provide important 350 insights on the factors driving the supplies of terrigenous sediments to Site U1429 through the 351 studied period. More specifically, our results demonstrate that the regional rainfall patterns 352 over the East Asian continent and the Japanese islands, as well as sea level changes, drive the 353 transfer of continental sediments to the northern tip of the Okinawa Trough over the last 354400 kyr. 
In contrast, the $\varepsilon_{\mathrm{Nd}}$ composition of the clay fraction through the last $400 \mathrm{kyr}$ is mostly controlled by contribution from Yellow River inputs (Section 4.3). One can assume that both sea-level variations and changes of the monsoonal rainfall pattern could explain the glacial/interglacial $\varepsilon_{\mathrm{Nd}}$ variability observed in this finest fraction (see the above discussion). However, considering the complexity of East Asian mainland geology, an alternative hypothesis may be that these $\varepsilon_{\mathrm{Nd}}$ changes reflect rainfall variability occurring within the drainage basin of the Yellow river in response to latitudinal shifts of the ITCZ. In fact, it is well known that present-day loess deposits from the northern-central part of the Yellow river are the main contributors of the Yellow river sediments discharges (Saito et al. 2001 and references therein; Yang et al., 2002; Hu et al., 2012). The Loess Plateau is characterized by $\varepsilon_{\mathrm{Nd}}$ signatures ranging from -12 to -7 (Table 3). This range of values is consistent with the $\varepsilon_{\mathrm{Nd}}$ recorded in the clay fraction deposited at Site U1429 (Figs 2 and 5), validating the hypothesis that the Loess Plateau controls the terrigenous sediment flux of the Yellow river sediment discharge over the last $400 \mathrm{kyr}$. The $\mathrm{Nd}$ isotopic signatures of the Chinese loess deposits are not geographically homogenous, however. For example, loess sequences encountered at the

370 Ordos Plateau, north of the Loess Plateau (Fig. 1), exhibit less radiogenic Nd isotopic signatures (from -21 to -10 ; Table 3), and increasing inputs from this source to the Yellow

372 River discharge during glacial periods could explain the observed $\varepsilon_{\mathrm{Nd}}$ changes. At present, the 373 Ordos Plateau is located at the northern end of the modern summer monsoon front (Fig. 1) 374 and receives little precipitations $(100-450 \mathrm{~mm} / \mathrm{yr})$ relative to the Loess Plateau (600$3751000 \mathrm{~mm} / \mathrm{yr}$; Porter et al., 2001; Xu et al., 2010). In addition, dry-and-cold winter monsoon 376 conditions prevailed during glacial intervals (e.g. An et al., 1990, 2000; Rousseau et al., 2009; 377 Jo et al., 2014). Consequently, if enhanced rainfall (and associated soil erosion) can increase 378 the contribution of the Loess Plateau to the Yellow river sediment discharge under summer 379 monsoon dominated interglacial conditions, aeolian processes are considered as the main 
driver to transport loess particles from the Ordos Plateau to the Yellow River (west of the

Taihang Mountains in particular) during glacial periods (Hu et al., 2012). Thus, the monsoon regime and, by extension, the latitudinal ITCZ shifts could explain the $\sim 2 \varepsilon_{\mathrm{Nd}}$ glacial-

383 interglacial difference observed in the geochemical signatures of the clay sediments deposited 384 at Site U1429. Enhanced dust inputs from the Ordos Plateau to the East China Sea, although difficult to quantify, certainly reinforce the glacial $\varepsilon_{\mathrm{Nd}}$ signature of clays observed at U1429.

386 Nevertheless, the riverine contribution is strongly supported by the $\sim 2 \varepsilon_{\mathrm{Nd}}$ shifts observed 387 between glacial and interglacial intervals (more precisely MIS 1 to 4 ) in the sediment from 388 the modern Yellow river delta, with contributions from the Ordos Plateau increasing during 389 MIS 2 and MIS 4 (Hu et al., 2012). The use of additional provenance proxies (e.g. ${ }^{87} \mathrm{Sr} /{ }^{86} \mathrm{Sr}$ 390 ratios; clay mineralogy) could help further constrain sediment sources and test the 391 aforementioned hypotheses. Regardless of the exact sources responsible for the observed 392 changes, the glacial/interglacial $\varepsilon_{\mathrm{Nd}}$ variability (and the recorded radiogenic nature of the 393 interglacial periods in particular) appears to reflect not only sea-level variations and 394 associated changes in oceanic circulation, but also changes in regional rainfall patterns over 395 the study area. This is particularly well supported by the $\varepsilon_{\mathrm{Nd}}$ variability observed within the 396 MIS 6 glacial period, specifically during MIS 6d (Fig. 2; Section 4.5).

\subsection{Zooming in on MIS 6}

The systematic glacial-interglacial $\varepsilon_{\mathrm{Nd}}$ variability (i.e., more radiogenic values during 400 interglacial intervals) identified through the last $400 \mathrm{kyr}$ at Site U1429 (Fig. 2) is particularly 401 clear for MIS 6 (and more specifically during the interval between ca. 150-180 ka, i.e., MIS 6d). As discussed previously, the non-cohesive silt fraction displays interglacial $\varepsilon_{\mathrm{Nd}}$ and REE characteristics that suggest increased inputs from the Loess Plateau and/or southern Japan (by 
comparison with glacial periods) in response to sea level changes as well as ITCZ migrations

405 and associated changes in monsoon systems intensities. One can assume that, for MIS 6, sea406 level variations, previously identified as a possible driver of orbital-scale variability in the $\varepsilon_{\mathrm{Nd}}$ 407 and REE, cannot explain the $\varepsilon_{\mathrm{Nd}}$ variability alone. First, the sea-level change associated with 408 MIS 6d (from $\sim-80$ to $\sim-50 \mathrm{~m}$ ) was relatively small $(\sim 30 \mathrm{~m})$ in comparison to 409 glacial/interglacial transitions (>100 m ;Waelbroeck et al., 2002; Grant et al., 2014). Second, 410 the MIS6d sea-level change would have presumably acted as a sediment trap in such a 411 shallow marine environment (e.g. Sweet \& Blum, 2016). A period of increased river 412 discharge can exceed the buffering effect of sea-level increases in the transfer of sediments 413 from terrestrial sources to deep basin sinks. Thus, we assume that enhanced rainfall occurred 414 over the Yellow river watershed and/or southern Japanese regions during MIS 6d, and by 415 extension that summer monsoon dominated conditions prevailed over East Asia. Such 416 conditions are quite unexpected for the MIS 6, however, since northern hemisphere ice-sheets 417 are known to have encouraged cold winter monsoon dominated conditions in East Asia (e.g. 418 Wang et al., 2008). Exceptionally high abundances of thermal-humidiphilous mollusks (a 419 species that is usually prevalent during interglacial periods) have been reported at ca. $170 \mathrm{ka}$ 420 in the Luochuan loess sequence (South Chinese Loess Plateau; Fig. 1), suggesting enhanced 421 summer monsoon (Rousseau et al., 2009). The same conclusion can also be drawn from both 422 Chinese (ca. 165-178 ka; Cheng et al., 2006; 2009; Wang et al., 2008) and Korean (ca. 168 $423 \mathrm{ka}$; Jo et al., 2014) speleothem records. In addition, sedimentological results from the Xifeng 424 loess sequence in the southern-central part of the Chinese Loess Plateau, about $150 \mathrm{~km}$ 425 westward of Luochuan, suggest intervals with particular weak winter monsoon during the 426 same interval (Guo et al., 2009). These results from the East Asian continent strongly support 427 our hypothesis that increased rainfall, and thus summer monsoon dominated conditions, 428 prevailed during the $\sim 150-180 \mathrm{ka}$ interval (MIS 6d). 
At a larger scale, intensification of the North African summer monsoon and associated

430 Nile discharges, in addition to unexpected wet conditions over the northern Mediterranean 431 borderlands (Ayalon et al., 2002; Bard et al., 2002; Toucanne et al., 2015), also led to the 432 deposition of the so-called sapropel S6 unit (ca. 165-178 ka, Ziegler et al., 2010; Rossignol433 Strick et al., 1983). This linkage between East Asia and North Africa indicates that both 434 regions may have been affected by synchronous, northward migration of the ITCZ. Thus, our 435 data independently support the idea that the ITCZ was located over northern China and the 436 southern Japan peninsula during MIS 6d. In agreement with recent work conducted on Korean speleothems (Jo et al., 2014), this reveals that our study area, as a mid-latitude temperate region and one of the northernmost parts of the East Asian monsoon sector, is significantly 439 influenced by migrations of the mean latitudinal position of the ITCZ.

\subsection{Long-term fluctuations of ITCZ}

A long-term change is observed in the $\varepsilon_{\mathrm{Nd}}$ profile at Site U1429 (Fig. 2). The $\varepsilon_{\mathrm{Nd}}$ data of the interglacial peaks show an increasing trend between MIS11 and MIS 5 (see Section 4.2). This trend is apparent for both the $<2 \mu \mathrm{m}$ and $30-63 \mu \mathrm{m}$ size fractions, allowing us to rule out the dust contribution (see Section 4.1). Similarly, long-term climatic fluctuations are preserved in the general evolution of $\delta^{18} \mathrm{O}$ hydrological records in Chinese (i.e. Kesang,

447 Sanbao and Hulu caves; Wang et al., 2008; Cheng et al., 2009, 2012, 2016) and Korean (Jo et 448 al., 2014) speleothems, as well as southern Australia (Ayliffe et al., 1998; Jo et al., 2014) (Fig. 449 2c, d), despite there being no discernable trend in the sea-level record (Waelbroeck et al., 450 2002; Grant et al., 2014) or oceanic circulation. The speleothem $\delta^{18} \mathrm{O}$ records, usually 451 interpreted as a proxy for summer monsoon intensity, can also reflect precipitation sources 452 (e.g., Pacific versus Indian Ocean; Clemens et al., 2010; Caley et al., 2014). It is difficult to 453 link possible changes in precipitation sources to the changes observed in our $\varepsilon_{\mathrm{Nd}}$ records, in 
454 particular for the Japanese peninsula and its small watersheds. Thus, the trend observed in 455 both Asian-Australian speleothem $\delta^{18} \mathrm{O}$ (Fig. 2c, d) and in the Okinawa Trough $\varepsilon_{\mathrm{Nd}}$ (Site 456 U1429 ; Fig. 2a) is most likely related to rainfall and summer monsoon intensity. On this 457 basis, we propose that the general evolution of the $\varepsilon_{\mathrm{Nd}}$ record at Site U1429 reflects a gradual 458 intensification of rainfall over East Asia (including the Yellow river watershed and the 459 southern Japan) and/or an increase of the duration of the wet season (i.e., summer monsoon) 460 in the same areas. Thus, taken together with the speleothem $\delta^{18} \mathrm{O}$ records from East Asia and 461 Australia, our data suggest a gradual, northward migration of the ITCZ during the successive 462 interglacials from MIS11 to MIS5. It could also reveal, in the light of the hydrological seesaw 463 pattern existing between East Asia and Australia (Jo et al., 2014), that the amplitude of the 464 variations (i.e. latitudinal amplitudes) in the seasonal ITCZ could have gradually increased 465 from MIS 11 to MIS 5. The assumptions detailed here require further testing. For example, 466 producing high-resolution inorganic (radiogenic and stable isotopes) and organic (e.g. long 467 chain n-alkanes; Pelejero, 2003) geochemical investigations at Site U1429. Nonetheless, by 468 providing the first long-term reconstruction of sediment discharge to the East China Sea 469 during the Quaternary, this study improves our understanding of changes in East Asian 470 monsoon dynamics and the attendant response of regional sediment routing systems over the $471 \quad$ last $400 \mathrm{kyr}$.

\section{Summary}

The REE and Nd isotopic compositions of the clay $(<2 \mu \mathrm{m})$ and non-cohesive silt $475(30-63 \mu \mathrm{m})$ detrital fractions of IODP Site U1429 sediments have been used to discuss 476 patterns of the sediment transfer into the northern East China Sea (Danjo Basin, northern 477 Okinawa Trough) over the last 400 kyr. Riverine inputs from the Yellow River and the 
Japanese archipelago have been identified as the main sediment sources. Their respective contributions at Site U1429 varied in phase with glacial-interglacial climate changes in response to both sea-level fluctuations, and the attendant reorganization of East Asian river mouth locations and ocean circulation on the East China Sea shelf, and latitudinal shifts of the ITCZ. Importantly, our results suggest a strengthening of the interglacial (summer) monsoon rainfall over the East Asian continent and Japan throughout the last $400 \mathrm{kyr}$, interpreted as a gradual northward migration of the ITCZ. Taken together with cave records, this study provides an indirect but valuable record of rainfall intensity over the East Asian continent and the Japanese Archipelago over the last four glacial-interglacial cycles and, by extension, new insights into the long-term evolution of the East Asian Monsoon.

\section{Acknowledgments}

Authors warmly thank N. Gayet and E. Pelleter for SEM analyses, S. Bermell for ArcGIS mapping, M.-L. Rouget for ICP-MS measurements, E. Ponzevera and Y. Germain for analyses with the Neptune MC-ICP-MS, and S. Chéron, J. Etoubleau, and A. Boissier for XRF measurements. Authors also express their special thanks to N. Freslon for help with ICPMS measurements, S. Boswell for English improvements, and A. Bory and V. BoutRoumazeilles for their support to the project. Authors finally thank all the scientific Expedition IODP 346 scientists, and Professor R. Tada (co-chief scientist) for his interest to this research. C.S. was partly supported by a Grant from the French government through Agence Nationale de la Recherche (ANR) under the 'Investissements d'Avenir' programme, reference ANR-10-LABX-19-0. 


\section{References}

502

503

504

505

506

507

508

509

510

511

512

513

514

515

516

517

518

519

520

521

522

523

An, Z., Tunghseng, L., Yanchou, L., Porter, S. C., Kukla, G. H. W. X., Xihao, W., \& Yingming, H. (1990). The long-term paleomonsoon variation recorded by the loesspaleosol sequence in central China. Quaternary International, 7, 91-95. DOI: $10.1016 / 1040-6182(90) 90042-3$.

An, Z., Porter, S. C., Kutzbach, J. E., Xihao, W., Suming, W., Xiaodong, L., Xiaoqiang, L., \& Weijian, Z. (2000). Asynchronous Holocene optimum of the East Asian monsoon. Quaternary Science Reviews, 19(8), 743-762. DOI: 10.1016/S0277-3791(99)00031-1.

Ayalon, A., Bar-Matthews, M., \& Kaufman, A. (2002). Climatic conditions during marine oxygen isotope stage 6 in the eastern Mediterranean region from the isotopic composition of speleothems of Soreq Cave, Israel. Geology, 30(4), 303-306. DOI: 10.1130/0091-7613(2002)030<0303:CCDMOI>2.2.CO;2.

Ayliffe, L. K., Marianelli, P. C., Moriarty, K. C., Wells, R. T., McCulloch, M. T., Mortimer, G. E., \& Hellstrom, J. C. (1998). 500 ka precipitation record from southeastern Australia: evidence for interglacial relative aridity. Geology, 26(2), 147-150.

Bard, E., Delaygue, G., Rostek, F., Antonioli, F., Silenzi, S., \& Schrag, D. P. (2002). Hydrological conditions over the western Mediterranean basin during the deposition of the cold Sapropel 6 (ca. 175 kyr BP). Earth and Planetary Science Letters, 202(2), 481-494. DOI: 10.1016/S0012-821X(02)00788-4.

Barrat, J. A., Keller, F., Amossé, J., Taylor, R. N., Nesbitt, R. W., \& Hirata, T. (1996). Determination of rare earth elements in sixteen silicate reference samples by ICP-MS after Tm addition and ion exchange separation. Geostandards and Geoanalytical Research, 20(1), 133-139. DOI: 10.1111/j.1751-908X.1996.tb00177.x. 
Bayon, G., German, C. R., Boella, R. M., Milton, J. A., Taylor, R. N., \& Nesbitt, R. W. (2002). An improved method for extracting marine sediment fractions and its application to $\mathrm{Sr}$ and $\mathrm{Nd}$ isotopic analysis. Chemical Geology, 187(3-4), 179-199. DOI: 10.1016/S0009-2541(01)00416-8.

Bayon, G., Barrat, J. A., Etoubleau, J., Benoit, M., Bollinger, C., \& Révillon, S. (2009). Determination of rare earth elements, Sc, Y, Zr, Ba, Hf and Th in geological samples by ICP-MS after Tm addition and alkaline fusion. Geostandards and Geoanalytical Research, 33(1), 51-62. DOI: 10.1111/j.1751-908X.2008.00880.x.

Bayon, G., Dennielou, B., Etoubleau, J., Ponzevera, E., Toucanne, S., \& Bermell, S. (2012). Intensifying weathering and land use in Iron Age Central Africa. Science, 335(6073), 1219-1222. DOI: $10.1126 /$ science.1215400.

Bayon, G., Toucanne, S., Skonieczny, C., André, L., Bermell, S., Cheron, S., Dennielou, B., Etoubleau, J., Freslon, N., Gauchery, T., Germain, Y., Jorry, S.J., Ménot, G., Monin, G., Ponzevera, E., Rouget, M-L, Tachikawa, K., \& Barrat, J.A. (2015). Rare earth elements and neodymium isotopes in world river sediments revisited. Geochimica et Cosmochimica Acta, 170, 17-38. DOI: 10.1016/j.gca.2015.08.001.

Beardsley, R. C., Limeburner, R., Yu, H., \& Cannon, G. A. (1985). Discharge of the Changjiang (Yangtze river) into the East China sea. Continental Shelf Research, 4(12), 57-76. DOI: 10.1016/0278-4343(85)90022-6.

Caley, T., Roche, D. M., \& Renssen, H. (2014). Orbital Asian summer monsoon dynamics revealed using an isotope-enabled global climate model. Nature communications, 5, 5371. DOI: $10.1038 /$ ncomms6371.

Chang, Y. P., Chen, M. T., Yokoyama, Y., Matsuzaki, H., Thompson, W. G., Kao, S. J., \& Kawahata, H. (2009). Monsoon hydrography and productivity changes in the East 
China Sea during the past 100,000 years: Okinawa Trough evidence (MD012404). Paleoceanography, 24(3). DOI: 10.1029/2007PA001577.

550 Chen, C. H., Jahn, B. M., Lee, T., Chen, C. H., \& Cornichet, J. (1990). Sm-Nd isotopic geochemistry of sediments from Taiwan and implications for the tectonic evolution of southeast China. Chemical Geology, 88(3-4), 317-332. DOI: 10.1016/0009-

Chen, C. H., DePaolo, D. J., Nakada, S., \& Shieh, Y. N. (1993). Relationship between 555 eruption volume and neodymium isotopic composition at Unzen volcano. Nature, 362(6423), 831. DOI: 10.1038/362831a0.

Chen, J., Wang, F., Meybeck, M., He, D., Xia, X., \& Zhang, L. (2005). Spatial and temporal analysis of water chemistry records (1958-2000) in the Huanghe (Yellow River) basin. Global biogeochemical cycles, 19(3). DOI: 10.1029/2004GB002325.

Chen, J., Li, G., Yang, J., Rao, W., Lu, H., Balsam, W., Sun, Y., \& Ji, J. (2007). Nd and Sr 561 isotopic characteristics of Chinese deserts: implications for the provenances of Asian dust. Geochimica et Cosmochimica Acta, 71(15), 3904-3914. DOI:

Chen, Z., Wang, Z., Schneiderman, J., Taol, J., \& Cail, Y. (2005). Holocene climate fluctuations in the Yangtze delta of eastern China and the Neolithic response. The Holocene, 15(6), 915-924. DOI: 10.1191/0959683605hl862rr.

Cheng, H., Edwards, R. L., Wang, Y., Kong, X., Ming, Y., Kelly, M. J., Zhang, \& Liu, W. 568 (2006). A penultimate glacial monsoon record from Hulu Cave and two-phase glacial terminations. Geology, 34(3), 217-220. DOI: 10.1130/G22289.1. 
Cheng, H., Edwards, R. L., Broecker, W. S., Denton, G. H., Kong, X., Wang, Y., Zhang, Y., \& Wang, X. (2009). Ice age terminations. Science, 326(5950), 248-252. DOI: 10.1126/science. 1177840 .

Cheng, H., Sinha, A., Wang, X., Cruz, F. W., \& Edwards, R. L. (2012). The Global Paleomonsoon as seen through speleothem records from Asia and the Americas. Climate Dynamics, 39(5), 1045-1062. DOI: 10.1007/s00382-012-1363-7.

Cheng, H., Edwards, R. L., Sinha, A., Spötl, C., Yi, L., Chen, S., Kelly, M., Kathayat, G., Wang, X., Li, X., Kong, X., Wang, Y., Ning, Y., \& Zhang, H. (2016). The Asian monsoon over the past 640,000 years and ice age terminations. Nature, 534(7609), 640. DOI: 10.1038/nature18591.

Clemens, S. C., Prell, W. L., \& Sun, Y. (2010). Orbital-scale timing and mechanisms driving Late Pleistocene Indo-Asian summer monsoons: Reinterpreting cave speleothem

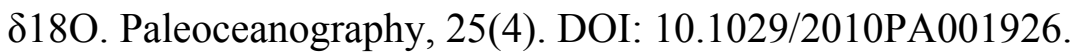

Diekmann, B., Hofmann, J., Henrich, R., Fütterer, D. K., Röhl, U., \& Wei, K. Y. (2008). Detrital sediment supply in the southern Okinawa Trough and its relation to sea-level and Kuroshio dynamics during the late Quaternary. Marine Geology, 255(1), 83-95. DOI: 10.1016/j.margeo.2008.08.001.

Dou, Y., Yang, S., Liu, Z., Clift, P. D., Shi, X., Yu, H., \& Berne, S. (2010). Provenance discrimination of siliciclastic sediments in the middle Okinawa Trough since $30 \mathrm{ka}$ : constraints from rare earth element compositions. Marine Geology, 275(1-4), 212-220. DOI: $10.1016 /$ j.margeo.2010.06.002.

Dou, Y., Yang, S., Liu, Z., Shi, X., Li, J., Yu, H., \& Berne, S. (2012). Sr-Nd isotopic constraints on terrigenous sediment provenances and Kuroshio Current variability in 
the Okinawa Trough during the late Quaternary. Palaeogeography, Palaeoclimatology, Palaeoecology, 365, 38-47. DOI: 10.1016/j.palaeo.2012.09.003.

595

596

597

598

599

600

601

602

603

604

605

606

607

608

609

610

611

612

613

614

615

616

Dykoski, C. A., Edwards, R. L., Cheng, H., Yuan, D., Cai, Y., Zhang, M., Lin, Y., Qing, J., An, J., \& Revenaugh, J. (2005). A high-resolution, absolute-dated Holocene and deglacial Asian monsoon record from Dongge Cave, China. Earth and Planetary Science Letters, 233(1-2), 71-86. DOI: 10.1016/j.eps1.2005.01.036.

Expedition 346 Scientists (2014), Asian Monsoon: onset and evolution of millennial-scale variability of Asian monsoon and its possible relation with Himalaya and Tibetan Plateau uplift. IODP Preliminary Report 346, 111p. DOI: 10.2204/iodp.proc.346.2015.

Feng, M., Mitsudera, H., \& Yoshikawa, Y. (2000). Structure and variability of the Kuroshio Current in Tokara Strait. Journal of Physical Oceanography, 30(9), 2257-2276. DOI: 10.1175/1520-0485(2000)030.

Garçon, M., \& Chauvel, C. (2014). Where is basalt in river sediments, and why does it matter?. Earth and Planetary Science Letters, 407, 61-69. DOI: 10.1016/j.eps1.2014.09.033.

Gao, Y., Arimoto, R., Duce, R. A., Zhang, X. Y., Zhang, G. Y., An, Z. S., Chen, L. Q., Zhou, M.Y., \& Gu, D. Y. (1997). Temporal and spatial distributions of dust and its deposition to the China Sea. Tellus B: Chemical and Physical Meteorology, 49(2), 172-189.

Goldstein, S. L., O'nions, R. K., \& Hamilton, P. J. (1984). A Sm-Nd isotopic study of atmospheric dusts and particulates from major river systems. Earth and planetary Science letters, 70(2), 221-236. DOI: 10.1016/0012-821X(84)90007-4.

Grant, K. M., Rohling, E. J., Ramsey, C. B., Cheng, H., Edwards, R. L., Florindo, F., Heslop, D., Marra, F., Roberts, A. P., Tamisiea, M. E. \& Williams, F. (2014). Sea-level 
variability over five glacial cycles. Nature communications, 5, 5076. DOI: 10.1038/ncomms6076.

Grousset, F. E., Parra, M., Bory, A., Martinez, P., Bertrand, P., Shimmield, G., \& Ellam, R. M. (1998). Saharan wind regimes traced by the $\mathrm{Sr}-\mathrm{Nd}$ isotopic composition of subtropical Atlantic sediments: last glacial maximum vs today. Quaternary Science Reviews, 17(4-5), 395-409. DOI: 10.1016/S0277-3791(97)00048-6.

Guo, Z. T., Berger, A., Yin, Q. Z., \& Qin, L. (2009). Strong asymmetry of hemispheric climates during MIS-13 inferred from correlating China loess and Antarctica ice records. Climate of the Past, 5(1), 21-31. DOI: 10.5194/cp-5-21-2009.

Hu, B., Li, G., Li, J., Bi, J., Zhao, J., \& Bu, R. (2012). Provenance and climate change inferred from $\mathrm{Sr}-\mathrm{Nd}-\mathrm{Pb}$ isotopes of late Quaternary sediments in the Huanghe (Yellow River) Delta, China. Quaternary Research, 78(3), 561-571. DOI: 10.1016/j.yqres.2012.07.005.

Huh, C. A., Su, C. C., Wang, C. H., Lee, S. Y., \& Lin, I. T. (2006). Sedimentation in the Southern Okinawa Trough—Rates, turbidites and a sediment budget. Marine Geology, 231(1-4), 129-139. DOI: 10.1016/j.margeo.2006.05.009.

Ishizaka, K., \& Carlson, R. W. (1983). Nd-Sr systematics of the Setouchi volcanic rocks, southwest Japan: a clue to the origin of orogenic andesite. Earth and Planetary Science Letters, 64(3), 327-340. DOI: 10.1016/0012-821X(83)90094-8.

Jacobsen, S. B., \& Wasserburg, G. J. (1980). Sm-Nd isotopic evolution of chondrites. Earth and Planetary Science Letters, 50(1), 139-155. DOI: 10.1016/0012-821X(80)90125-9.

Jian, Z., Wang, P., Saito, Y., Wang, J., Pflaumann, U., Oba, T., \& Cheng, X. (2000). Holocene variability of the Kuroshio current in the Okinawa Trough, northwestern 
Pacific Ocean. Earth and Planetary Science Letters, 184(1), 305-319. DOI: $10.1016 / \mathrm{S} 0012-821 \mathrm{X}(00) 00321-6$.

642

643

644

645

646

647

648

649

650

651

652

653

654

655

656

657

658

659

660

661

Jo, K. N., Woo, K. S., Yi, S., Yang, D. Y., Lim, H. S., Wang, Y., Cheng, H., \& Edwards, R. L. (2014). Mid-latitude interhemispheric hydrologic seesaw over the past 550,000 years. Nature, 508(7496), 378. DOI: 10.1038/nature13076.

John, B. M., Zhou, X. H., \& Li, J. L. (1990). Formation and tectonic evolution of southeastern China and Taiwan: isotopic and geochemical constraints. Tectonophysics, 183(1-4), 145-160. DOI: 10.1016/0040-1951(90)90413-3.

Kapp, P., Pelletier, J. D., Rohrmann, A., Heermance, R., Russell, J., \& Ding, L. (2011). Wind erosion in the Qaidam basin, central Asia: implications for tectonics, paleoclimate, and the source of the Loess Plateau. GsA Today, 21(4/5), 4-10. DOI: 10.1130/GSATG99A.1.

Kao, S. J., Wu, C. R., Hsin, Y. C., \& Dai, M. (2006). Effects of sea level change on the upstream Kuroshio Current through the Okinawa Trough. Geophysical research letters, 33(16). DOI: 10.1029/2006GL026822.

Kubota, Y., Kimoto, K., Tada, R., Oda, H., Yokoyama, Y., \& Matsuzaki, H. (2010). Variations of East Asian summer monsoon since the last deglaciation based on $\mathrm{Mg} / \mathrm{Ca}$ and oxygen isotope of planktic foraminifera in the northern East China Sea. Paleoceanography, 25(4). DOI: 10.1029/2009PA001891.

Lan, C. Y., Lee, T., Zhou, X. H., \& Kwon, S. T. (1995). Nd isotopic study of Precambrian basement of South Korea: Evidence for Early Archean crust?. Geology, 23(3), 249252. DOI: $10.1130 / 0091-7613(1995) 023$. 
Laskar, J., Robutel, P., Joutel, F., Gastineau, M., Correia, A. C. M., \& Levrard, B. (2004). A long-term numerical solution for the insolation quantities of the Earth. Astronomy \& Astrophysics, 428(1), 261-285. DOI: 10.1051/0004-6361:20041335.

Lee, H. J., \& Chao, S. Y. (2003). A climatological description of circulation in and around the East China Sea. Deep Sea Research Part II: Topical Studies in Oceanography, 50(6-7), 1065-1084. DOI: 10.1016/S0967-0645(03)00010-9.

Lee, S. R., Cho, M., Hwang, J. H., Lee, B. J., Kim, Y. B., \& Kim, J. C. (2003). Crustal evolution of the Gyeonggi massif, South Korea: Nd isotopic evidence and implications for continental growths of East Asia. Precambrian Research, 121(1-2), 25-34. DOI: 10.1016/s0301-9268(02)00196-1.

Li, C. S., Shi, X. F., Kao, S. J., Liu, Y. G., Lyu, H. H., Zou, J. J., Liu, S-F., \& Qiao, S. Q. (2013). Rare earth elements in fine-grained sediments of major rivers from the highstanding island of Taiwan. Journal of Asian Earth Sciences, 69, 39-47. DOI: 10.1016/j.jseaes.2013.03.001.

Li, T., Xu, Z., Lim, D., Chang, F., Wan, S., Jung, H., \& Choi, J. (2015). Sr-Nd isotopic constraints on detrital sediment provenance and paleoenvironmental change in the northern Okinawa Trough during the late Quaternary. Palaeogeography, Palaeoclimatology, Palaeoecology, 430, 74-84. DOI: 10.1016/j.palaeo.2015.04.017.

Lin, A., Yang, Z., Sun, Z., \& Yang, T. (2001). How and when did the Yellow River develop its square bend?. Geology, 29(10), 951-954. DOI: 10.1130/0091-7613.

Liu, C. Q., Masuda, A., Okada, A., Yabuki, S., \& Fan, Z. L. (1994). Isotope geochemistry of Quaternary deposits from the arid lands in northern China. Earth and Planetary Science Letters, 127(1-4), 25-38. DOI: 10.1016/0012-821X(94)90195-3. 
Liu, Z., Trentesaux, A., Clemens, S. C., Colin, C., Wang, P., Huang, B., \& Boulay, S. (2003). Clay mineral assemblages in the northern South China Sea: implications for East Asian monsoon evolution over the past 2 million years. Marine Geology, 201(1), 133146. DOI: $10.1016 / \mathrm{S} 0025-3227(03) 00213-5$.

Liu, J. P., Xu, K. H., Li, A. E. A., Milliman, J. D., Velozzi, D. M., Xiao, S. B., \& Yang, Z. S. (2007). Flux and fate of Yangtze River sediment delivered to the East China Sea. Geomorphology, 85(3-4), 208-224. DOI: 10.1016/j.geomorph.2006.03.023.

Lugmair, G. W., Shimamura, T., Lewis, R. S., \& Anders, E. (1983). Samarium-146 in the early solar system: evidence from neodymium in the Allende meteorite. science, 222(4627), 1015-1018. DOI: 10.1126/science.222.4627.1015.

Mahoney, J. B. (2005). Nd and Sr isotopic signatures of fine-grained clastic sediments: A case study of western Pacific marginal basins. Sedimentary Geology, 182(1), 183-199. DOI: 10.1016/j.sedgeo.2005.07.009.

Meng, X., Liu, L., Wang, X. T., Balsam, W., Chen, J., \& Ji, J. (2018). Mineralogical evidence of reduced East Asian summer monsoon rainfall on the Chinese loess plateau during the early Pleistocene interglacials. Earth and Planetary Science Letters, 486, 61-69. DOI: $10.1016 /$ j.epsl.2017.12.048.

Meyer, I., Davies, G. R., \& Stuut, J. B. W. (2011). Grain size control on Sr-Nd isotope provenance studies and impact on paleoclimate reconstructions: An example from deep-sea sediments offshore NW Africa. Geochemistry, Geophysics, Geosystems, 12(3). DOI: 10.1029/2010GC003355.

Milliman, J. D., Yun-Shan, Q., Mei-e, R., \& Saito, Y. (1987). Man's influence on the erosion and transport of sediment by Asian rivers: the Yellow River (Huanghe) example. The Journal of Geology, 95(6), 751-762. DOI: 10.1086/629175. 
Milliman, J. D., \& Syvitski, J. P. (1992). Geomorphic/tectonic control of sediment discharge to the ocean: the importance of small mountainous rivers. The Journal of Geology, 100(5), 525-544. DOI: 10.1086/629606.

Nagashima, K., Tada, R., Tani, A., Sun, Y., Isozaki, Y., Toyoda, S., \& Hasegawa, H. (2011). Millennial-scale oscillations of the westerly jet path during the last glacial period. Journal of Asian Earth Sciences, 40(6), 1214-1220. DOI: 10.1016/j.jseaes.2010.08.010.

Nakano, T., Yokoo, Y., Nishikawa, M., \& Koyanagi, H. (2004). Regional Sr-Nd isotopic ratios of soil minerals in northern China as Asian dust fingerprints. Atmospheric Environment, 38(19), 3061-3067. DOI: 10.1016/j.atmosenv.2004.02.016.

Oiwane, H., Tonai, S., Kiyokawa, S., Nakamura, Y., Suganuma, Y., \& Tokuyama, H. (2011). Geomorphological development of the Goto Submarine Canyon, northeastern East China Sea. Marine Geology, 288(1-4), 49-60. DOI: 10.1016/j.margeo.2011.06.013.

Pelejero, C. (2003). Terrigenous n-alkane input in the South China Sea: high-resolution records and surface sediments. Chemical Geology, 200(1-2), 89-103. DOI: 10.1016/S0009-2541(03)00164-5.

Porter, S. C., Hallet, B., Wu, X., \& An, Z. (2001). Dependence of near-surface magnetic susceptibility on dust accumulation rate and precipitation on the Chinese Loess Plateau. Quaternary Research, 55(3), 271-283. DOI: 10.1006/qres.2001.2224.

Pullen, A., Kapp, P., McCallister, A. T., Chang, H., Gehrels, G. E., Garzione, C. N., Heermance, R. V., \& Ding, L. (2011). Qaidam Basin and northern Tibetan Plateau as dust sources for the Chinese Loess Plateau and paleoclimatic implications. Geology, 39(11), 1031-1034. DOI: 10.1130/G32296.1. 
Railsback, L. B., Gibbard, P. L., Head, M. J., Voarintsoa, N. R. G., \& Toucanne, S. (2015). An optimized scheme of lettered marine isotope substages for the last 1.0 million years, and the climatostratigraphic nature of isotope stages and substages. Quaternary Science Reviews, 111, 94-106. DOI: 10.1016/j.quascirev.2015.01.012.

Rossignol-Strick, M. (1983). African monsoons, an immediate climate response to orbital insolation. Nature, 304(5921), 46. DOI: 10.1038/304046a0.

Rousseau, D. D., Wu, N., Pei, Y., \& Li, F. (2009). Three exceptionally strong East-Asian summer monsoon events during glacial times in the past 470 kyr. Climate of the Past, 5(2), 157-169. DOI: 10.5194/cp-5-157-2009.

Sagawa, T., Nagahashi, Y., Satoguchi, Y., Holbourn, A., Itaki, T., Gallagher, S. J., SaaverdraPellitero, M., Ikheara, K., Irino, T. \& Tada, R. (2018). Integrated tephrostratigraphy and stable isotope stratigraphy in the Japan Sea and East China Sea using IODP Sites U1426, U1427, and U1429, Expedition 346 Asian Monsoon. Progress in Earth and Planetary Science, 5(1), 18. DOI: 10.1186/s40645-018-0168-7.

Saito, Y., Yang, Z., \& Hori, K. (2001). The Huanghe (Yellow River) and Changjiang (Yangtze River) deltas: a review on their characteristics, evolution and sediment discharge during the Holocene. Geomorphology, 41(2-3), 219-231. DOI: 10.1016/S0169-555X(01)00118-0.

Sun, Y., Oppo, D. W., Xiang, R., Liu, W., \& Gao, S. (2005). Last deglaciation in the Okinawa Trough: Subtropical northwest Pacific link to Northern Hemisphere and tropical climate. Paleoceanography, 20(4). DOI: 10.1029/2004PA001061.

Sun, Y., Clemens, S. C., An, Z., \& Yu, Z. (2006). Astronomical timescale and palaeoclimatic implication of stacked 3.6-Myr monsoon records from the Chinese Loess Plateau. Quaternary Science Reviews, 25(1-2), 33-48. DOI: 10.1016/j.quascirev.2005.07.005. 
Sun, Y., Tada, R., Chen, J., Liu, Q., Toyoda, S., Tani, A., Ji, J., \& Isozaki, Y. (2008). Tracing the provenance of fine-grained dust deposited on the central Chinese Loess Plateau. Geophysical Research Letters, 35(1). DOI: 10.1029/2007GL031672.

Sweet, M. L., \& Blum, M. D. (2016). Connections between fluvial to shallow marine environments and submarine canyons: Implications for sediment transfer to deep water. Journal of Sedimentary Research, 86(10), 1147-1162. DOI: 10.2110/jsr.2016.64.

Tanaka, T., Togashi, S., Kamioka, H., Amakawa, H., Kagami, H., Hamamoto, T., Yuhara, M., Orihashi, Y., Yoneda, S., Shimizu, H., Kunimaru, T., Takahashi, K., Yanagi, T., Nakano, T., Fujimaki, H., Shinjo, R., Asahara, Y., Tanimizu, M., \& Dragusanu, C. (2000). JNdi-1: a neodymium isotopic reference in consistency with LaJolla neodymium. Chemical Geology, 168(3-4), 279-281. DOI: 10.1016/S00092541(00)00198-4.

Toucanne, S., Minto'o, C. M. A., Fontanier, C., Bassetti, M. A., Jorry, S. J., \& Jouet, G. (2015). Tracking rainfall in the northern Mediterranean borderlands during sapropel deposition. Quaternary Science Reviews, 129, 178-195. DOI: 10.1016/j.quascirev.2015.10.016.

Ujiie, H., Tanaka, Y., \& Ono, T. (1991). Late Quarternary paleoceanographic record from the middle Ryukyu Trench slope, northwest Pacific. Marine Micropaleontology, 18(1-2), 115-128. DOI: 10.1016/0377-8398(91)90008-T.

Ujiié, H., \& Ujiié, Y. (1999). Late Quaternary course changes of the Kuroshio Current in the Ryukyu Arc region, northwestern Pacific Ocean. Marine Micropaleontology, 37(1), 23-40. DOI: 10.1016/S0377-8398(99)00010-9. 
Ujiié, Y., Ujiié, H., Taira, A., Nakamura, T., \& Oguri, K. (2003). Spatial and temporal variability of surface water in the Kuroshio source region, Pacific Ocean, over the past 21,000 years: evidence from planktonic foraminifera. Marine Micropaleontology, 49(4), 335-364. DOI: 10.1016/S0377-8398(03)00062-8.

Waelbroeck, C., Labeyrie, L., Michel, E., Duplessy, J. C., McManus, J. F., Lambeck, K., Balbon, E., \& Labracherie, M. (2002). Sea-level and deep water temperature changes derived from benthic foraminifera isotopic records. Quaternary Science Reviews, 21(1-3), 295-305. DOI: 10.1016/S0277-3791(01)00101-9.

Wang, L., Sarnthein, M., Erlenkeuser, H., Grimalt, J., Grootes, P., Heilig, S., Ivanova, E., Kienast, M., Pelejeroc, C., \& Pflaumann, U. (1999). East Asian monsoon climate during the Late Pleistocene: high-resolution sediment records from the South China Sea. Marine Geology, 156(1), 245-284. DOI: 10.1016/S0025-3227(98)00182-0.

Wang, Y. J., Cheng, H., Edwards, R. L., An, Z. S., Wu, J. Y., Shen, C. C., \& Dorale, J. A. (2001). A high-resolution absolute-dated late Pleistocene monsoon record from Hulu Cave, China. science, 294(5550), 2345-2348. DOI: 10.1126/science.1064618.

Wang, Y., Cheng, H., Edwards, R. L., Kong, X., Shao, X., Chen, S., WU, J., Jiang, X., Wang, X. \& An, Z. (2008). Millennial-and orbital-scale changes in the East Asian monsoon over the past 224,000 years. Nature, 451(7182), 1090. DOI: $10.1038 /$ nature06692.

Xiao, J. L., An, Z. S., Liu, T. S., Inouchi, Y., Kumai, H., Yoshikawa, S., \& Kondo, Y. (1999). East Asian monsoon variation during the last 130,000 years: evidence from the Loess Plateau of central China and Lake Biwa of Japan. Quaternary Science Reviews, 18(1), 147-157. DOI: 10.1016/S0277-3791(97)00097-8.

Xiao, J., Xu, Q., Nakamura, T., Yang, X., Liang, W., \& Inouchi, Y. (2004). Holocene vegetation variation in the Daihai Lake region of north-central China: a direct 
indication of the Asian monsoon climatic history. Quaternary Science Reviews, 23(1415), 1669-1679. DOI: 10.1016/j.quascirev.2004.01.005.

Xiao, S., Li, A., Liu, J. P., Chen, M., Xie, Q., Jiang, F., Li, T., Xiang, R., \& Chen, Z. (2006). Coherence between solar activity and the East Asian winter monsoon variability in the past 8000 years from Yangtze River-derived mud in the East China Sea. Palaeogeography, Palaeoclimatology, Palaeoecology, 237(2-4), 293-304. DOI: 10.1016/j.palaeo.2005.12.003.

Xu, D. Y., Kang, X. W., Zhuang, D. F., \& Pan, J. J. (2010). Multi-scale quantitative assessment of the relative roles of climate change and human activities in desertification-A case study of the Ordos Plateau, China. Journal of Arid Environments, 74(4), 498-507. DOI: 10.1016/j.jaridenv.2009.09.030.

Xu, Z., Li, T., Chang, F., Wan, S., Choi, J., \& Lim, D. (2014). Clay-sized sediment provenance change in the northern Okinawa Trough since $22 \mathrm{kyrBP}$ and its paleoenvironmental implication. Palaeogeography, Palaeoclimatology, Palaeoecology, 399, 236-245. DOI: 10.1016/j.palaeo.2014.01.016.

Yang, S. Y., Jung, H. S., Choi, M. S., \& Li, C. X. (2002). The rare earth element compositions of the Changjiang (Yangtze) and Huanghe (Yellow) river sediments. Earth and Planetary Science Letters, 201(2), 407-419. DOI: 10.1016/S0012$821 \mathrm{X}(02) 00715-\mathrm{X}$.

Yang, S., Jiang, S., Ling, H., Xia, X., Sun, M., \& Wang, D. (2007). Sr-Nd isotopic compositions of the Changjiang sediments: Implications for tracing sediment sources. Science in China Series D: Earth Sciences, 50(10), 1556-1565. DOI: 10.1007/s11430007-0052-6. 
Yang, S., \& Ding, Z. (2008). Advance-retreat history of the East-Asian summer monsoon rainfall belt over northern China during the last two glacial-interglacial cycles. Earth and Planetary Science Letters, 274(3-4), 499-510. DOI: 10.1016/j.eps1.2008.08.001.

Yi, S., Saito, Y., Zhao, Q., \& Wang, P. (2003). Vegetation and climate changes in the Changjiang (Yangtze River) Delta, China, during the past 13,000 years inferred from pollen records. Quaternary Science Reviews, 22(14), 1501-1519. DOI: 10.1016/S0277-3791(03)00080-5.

Yi, S., \& Saito, Y. (2004). Latest Pleistocene climate variation of the East Asian monsoon from pollen records of two East China regions. Quaternary International, 121(1), 7587. DOI: 10.1016/j.quaint.2004.02.017.

Yu, H., Liu, Z., Berné, S., Jia, G., Xiong, Y., Dickens, G. R., Wei, G., Shi, X., Liu, J. P., \& Chen, F. (2009). Variations in temperature and salinity of the surface water above the middle Okinawa Trough during the past 37 kyr. Palaeogeography, Palaeoclimatology, Palaeoecology, 281(1-2), 154-164. DOI: 10.1016/j.palaeo.2009.08.002.

Yuan, D., Cheng, H., Edwards, R. L., Dykoski, C. A., Kelly, M. J., Zhang, M., Qing, J., Lin, Y., Wang, Y., Wu, J., Dorale, J. A., An., Z., \& Cai, Y. (2004). Timing, duration, and transitions of the last interglacial Asian monsoon. Science, 304(5670), 575-578. DOI: 10.1126/science. 1091220 .

Zhao, D., Wan, S., Toucanne, S., Clift, P. D., Tada, R., Révillon, S., Kubota, Y., Zheng, X., Yu, Z., Huang, J., Jiang, H., Xu, Z., Shi, X, \& Li, A. (2017). Distinct control mechanism of fine-grained sediments from Yellow River and Kyushu supply in the northern Okinawa Trough since the last glacial. Geochemistry, Geophysics, Geosystems. DOI: 10.1002/2016GC006764. 
850 Zhao, D., Wan, S., Clift, P. D., Tada, R., Huang, J., Yin, X., Liao, X., Shen, X., Shi, X., \& Li, A. (2018). Provenance, sea-level and monsoon climate controls on silicate weathering of Yellow River sediment in the northern Okinawa Trough during late last glaciation. Palaeogeography, Palaeoclimatology, Palaeoecology, 490, 227-239. DOI: 10.1016/j.palaeo.2017.11.002.

855 Zhisheng, A., Kutzbach, J. E., Prell, W. L., \& Porter, S. C. (2001). Evolution of Asian monsoons and phased uplift of the Himalaya-Tibetan plateau since Late Miocene times. nature, 411(6833), 62. DOI: 10.1038/35075035.

858 Ziegler, M., Tuenter, E., \& Lourens, L. J. (2010). The precession phase of the boreal summer 859 monsoon as viewed from the eastern Mediterranean (ODP Site 968). Quaternary

860 Science Reviews, 29(11), 1481-1490. DOI: 10.1016/j.quascirev.2010.03.011.

861

862 


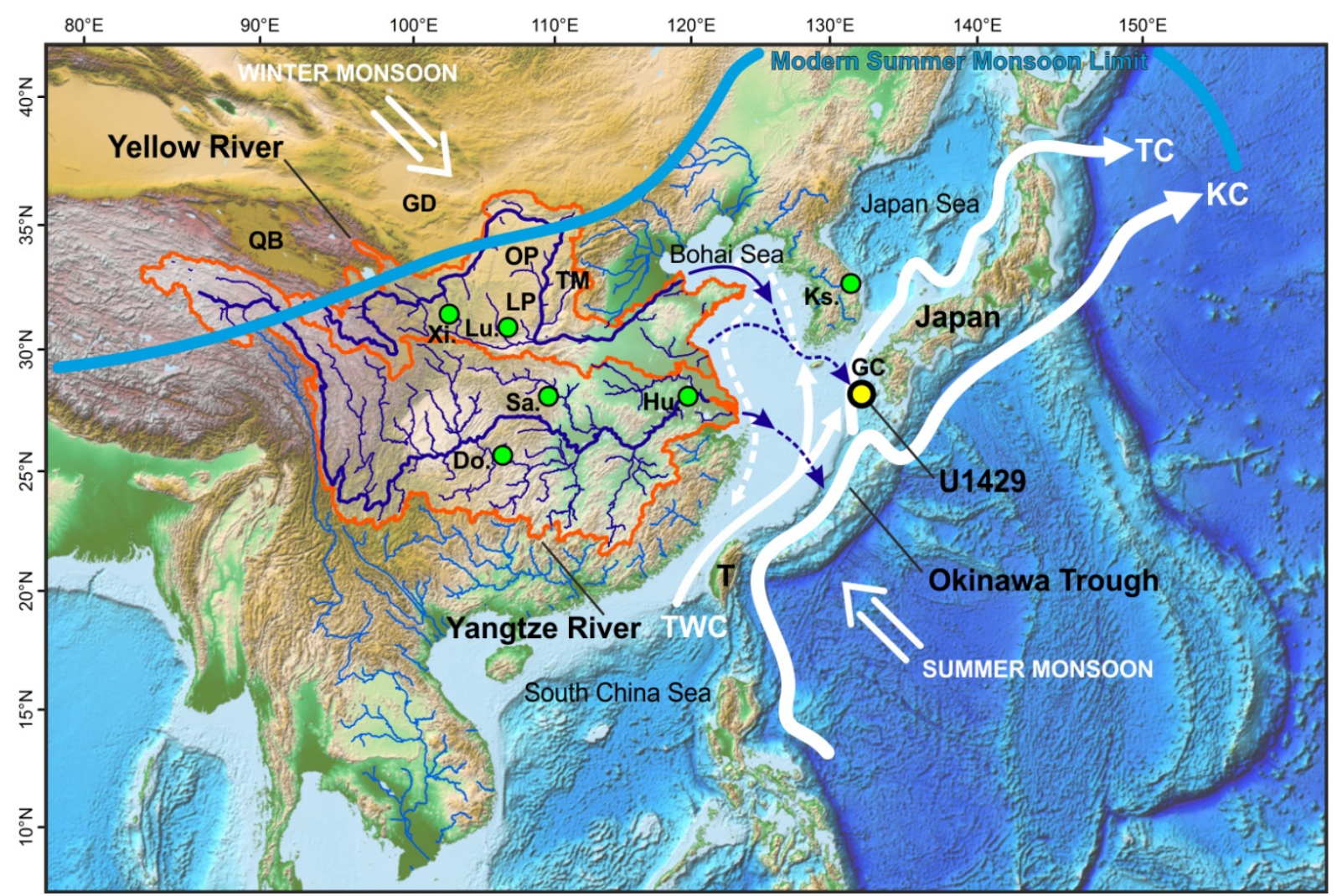

FIGURE 1: Map of the study area showing the limit of modern summer monsoon front (light blue line; An et al., 2000; Jo et al., 2014), the drainage area of the Yangtze and Yellow rivers (with their glacial lowstand courses, dark blue lines; Ujiié \& Ujiié, 1999; Oiwane et al., 2011; $\mathrm{Xu}$ et al., 2014) and the location of Site U1429 (yellow circle; Expedition 346 Scientists, 2014). The thick white arrows depict the regional ocean circulation (TC: Tsushima Current; KC: Kuroshio Current; Lee and Chao, 2003; Liu et al., 2007). The thin white arrows on the East China Sea shelf depict the Taiwan Warm Current (continuous, TWC) and the Yellow Sea Warm Current (dashed), respectively (Lee and Chao, 2003; Liu et al., 2007). The green circles denote the continental sequences (e.g. loess deposits, speleothems) discussed in the text (from West to East: Dongge Cave -Do.-, Sanbao Cave -Sa.-, Luochuan loess sequence Lu.-, Hulu Cave -Hu.-, Korean speleothems -Ks.-). Also shown is the location of the Qaidam Basin (QB), Gobi Desert (GD), Ordos Plateau (OP), Loess Plateau (LP), Taihang Mountains 880 (TM), Taiwan (T), and the Goto Submarine Canyon (GC). 


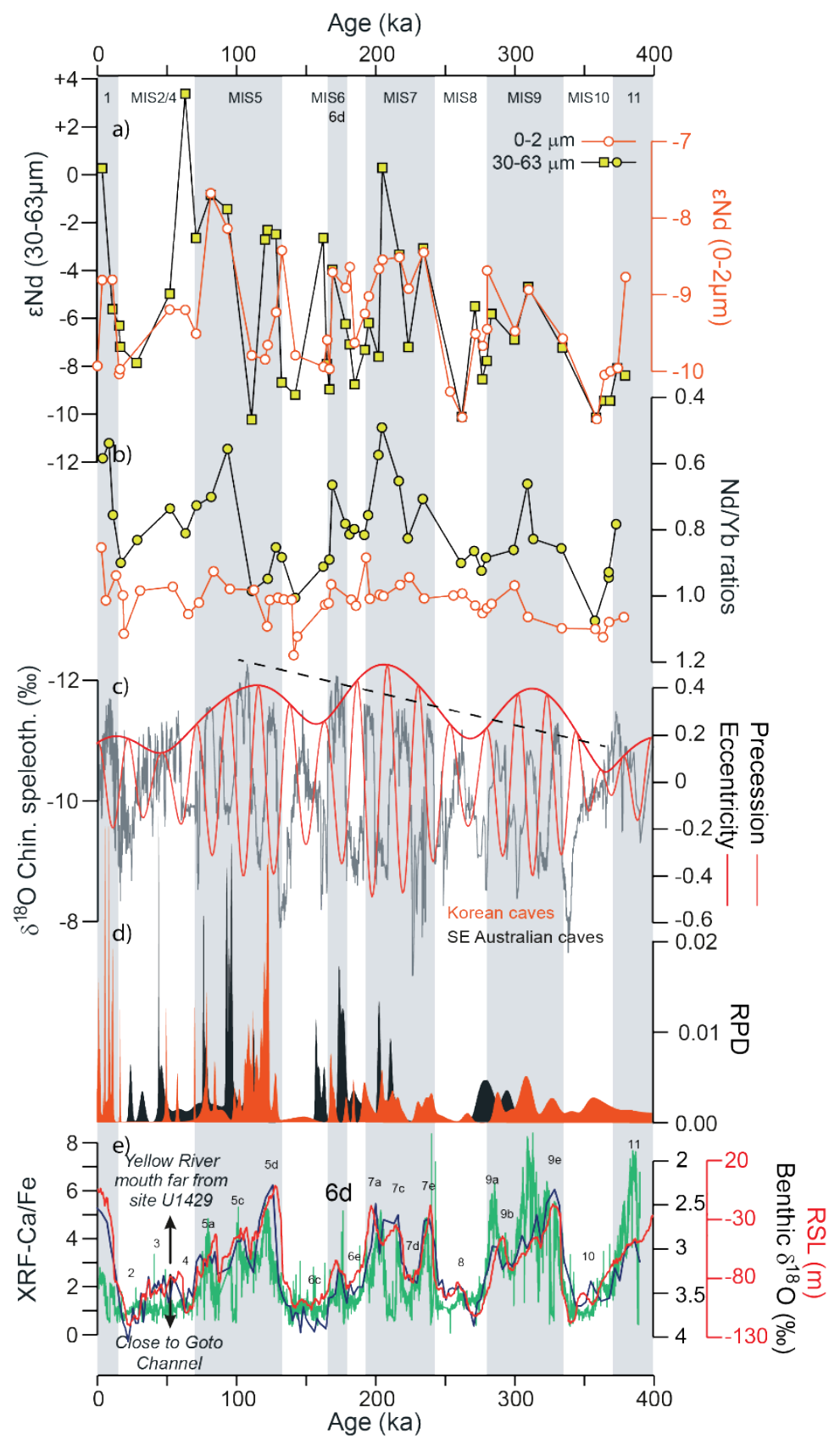

FIGURE 2: Comparison of U1429 geochemical proxies (i.e., Nd, REE, XRF elemental analysis) with other climate records. Chinese speleothems: Cheng et al. (2012, 2016); Excentricity and precession: Laskar et al. (2004); Relative Probability Density (RPD, speleothem growth): Jo et al. (2014); $\delta^{18} \mathrm{O}$ of benthic forams from Site U1429: Sagawa et al. (2018); scheme of marine isotope substages (MIS): Railsback et al. (2015). $\varepsilon_{\mathrm{Nd}}$ values of the $<$ $2 \mu \mathrm{m}$ grain-size fraction exhibit small glacial/interglacial variability $\left(\sim 2 \varepsilon_{\mathrm{Nd}}\right)$ compared to the 30-63 $\mu \mathrm{m}$ grain-size fraction $\left(>6 \varepsilon_{\mathrm{Nd}}\right.$ ). Both these fractions are characterized by a general trend over the last $400 \mathrm{kyr}$ showing a progressive increase of the interglacial $\varepsilon_{\mathrm{Nd}}$ values. Note that this trend is also visible in the glacial $\varepsilon_{\mathrm{Nd}}$ values from the $<2 \mu \mathrm{m}$ grain-size fraction. The $\mathrm{Nd} / \mathrm{Yb}$ ratio of the $<2 \mu \mathrm{m}$ grain-size fraction stays relatively constant and close to WRAS composition throughout most of the interval. On the other hand, the $\mathrm{Nd} / \mathrm{Yb}$ ratios of the 30$63 \mu \mathrm{m}$ grain-size fraction display strong glacial/interglacial variability with lower values during the interglacial periods. Dashed line (c) shows the long term trend visible in the $\delta^{18} \mathrm{O}$. 


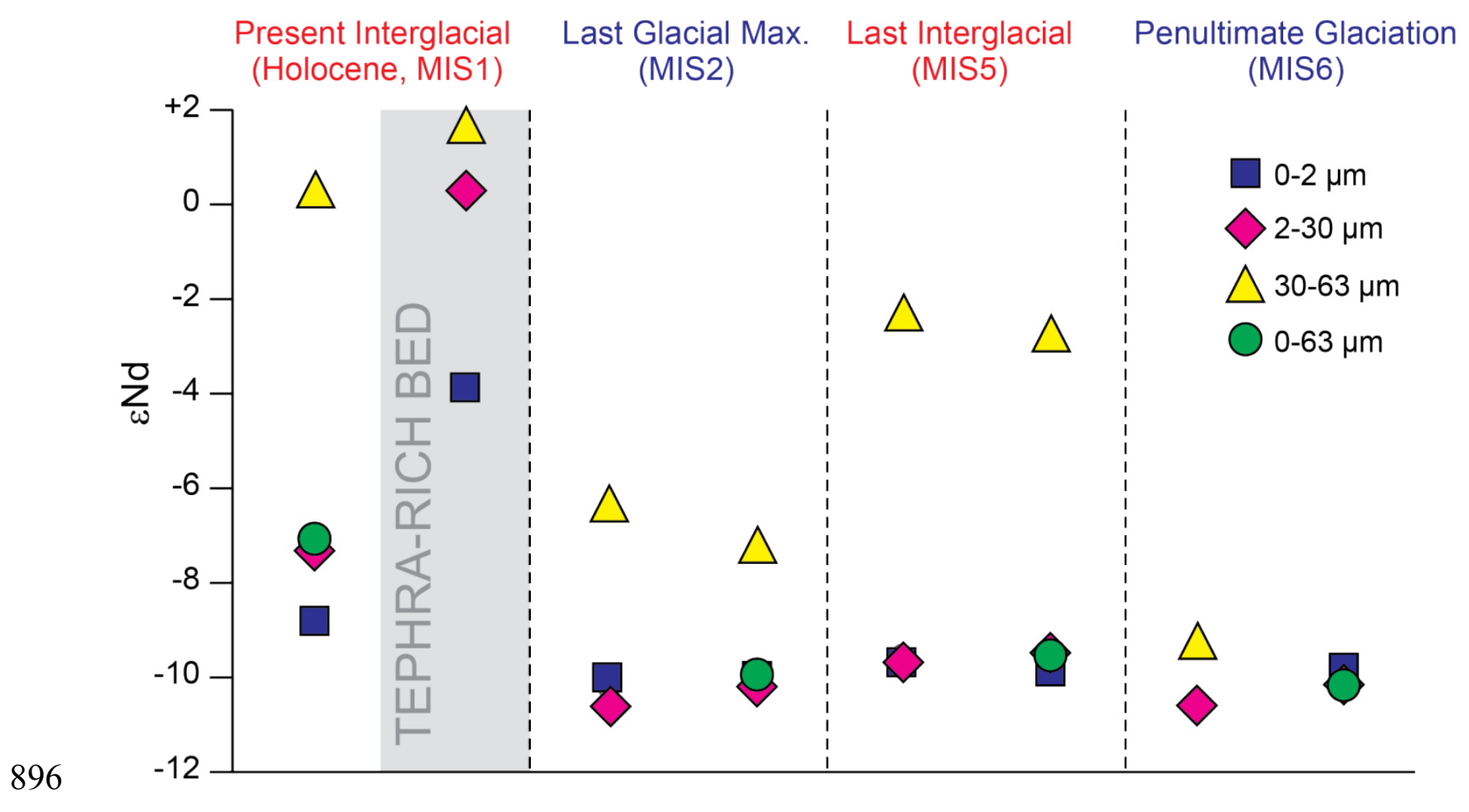

898 FIGURE 3: Relationship between $\varepsilon_{\mathrm{Nd}}$ values and grain-size fraction for 8 key samples from 899 Site U1429. Note that we were not able to measure $\varepsilon_{\mathrm{Nd}}$ for the $30-63 \mu \mathrm{m}$ fraction of the 900 second MIS 6 sample due to a lack of material. All samples from the $<2 \mu \mathrm{m}, 2-30 \mu \mathrm{m}$, and 0 $90163 \mu \mathrm{m}$ fractions are characterized by unradiogenic $\varepsilon_{\mathrm{Nd}}$ values between -11 and -7 , whereas the $90230-63 \mu \mathrm{m}$ fraction exhibits high glacial/interglacial variability with unradiogenic values 903 during glacials and radiogenic values during interglacials. Note that the Holocene tephra-rich 904 bed correspond to the Kikai-Akahoya eruption ( $\sim 7.2 \mathrm{ka})$ originating from Kyushu island (see 905 Sagawa et al., 2018 and references therein). 

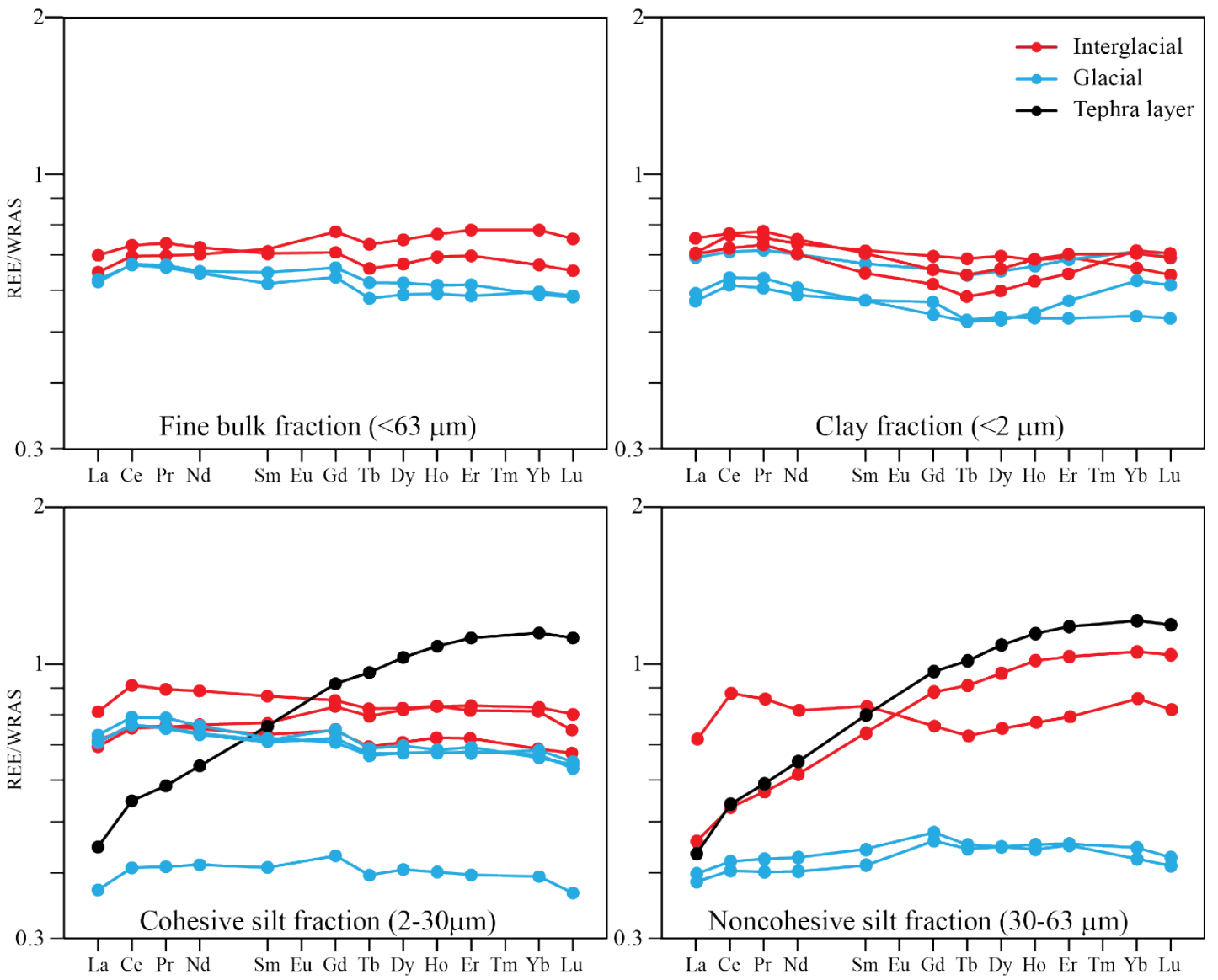

FIGURE 4: WRAS-normalized REE compositions of test samples at Site U1429. WRAS: World River Average Silts. Note that less samples have been analyzed in the coarse fractions (0-63 $\mu \mathrm{m}$ and 30-63 $\mu \mathrm{m})$ due to the paucity of certain sediments. For similar reasons, REE analyses were not performed on the $0-63 \mu \mathrm{m}$ size fraction of the tephra sample. Priority was given to $\mathrm{Nd}$ isotopes in all cases. All glacial samples exhibit REE patterns similar to the WRAS composition. Interglacial sample REE compositions are similar to the glacial samples for the $<2 \mu \mathrm{m}, 2-30 \mu \mathrm{m}$, and 0-63 $\mu \mathrm{m}$ grain-size fractions, but are more similar to the tephra sample in the 30-63 $\mu \mathrm{m}$ grain-size fraction, thus indicating Japanese provenance. In all grainsize fractions, the REE-depleted character of the glacial samples is more pronounced than for interglacial samples due to higher biogenic silica (characterized by very low REE concentration) content in the former. 


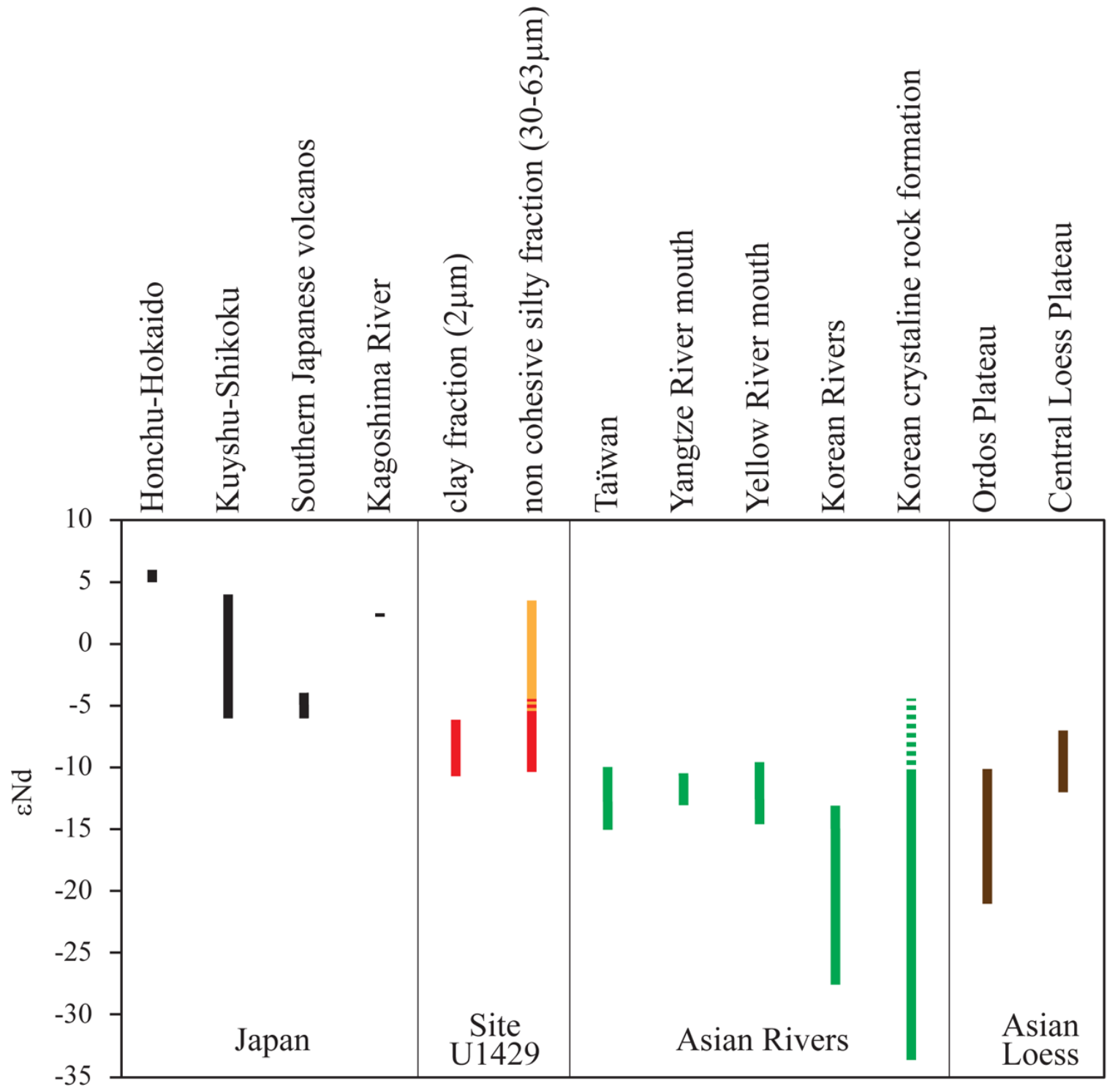

923 FIGURE 5: $\varepsilon_{\mathrm{Nd}}$ values of sediments from Site U1429 and potential sources (see Table 3 for 924 detailed references). Red corresponds to the samples from Site U1429 characterized by 925 WRAS-like REE patterns, whereas orange represents the samples with a typical volcanic 926 signature (i.e. southern Japanese rivers) in both Nd isotopes and REE composition. 

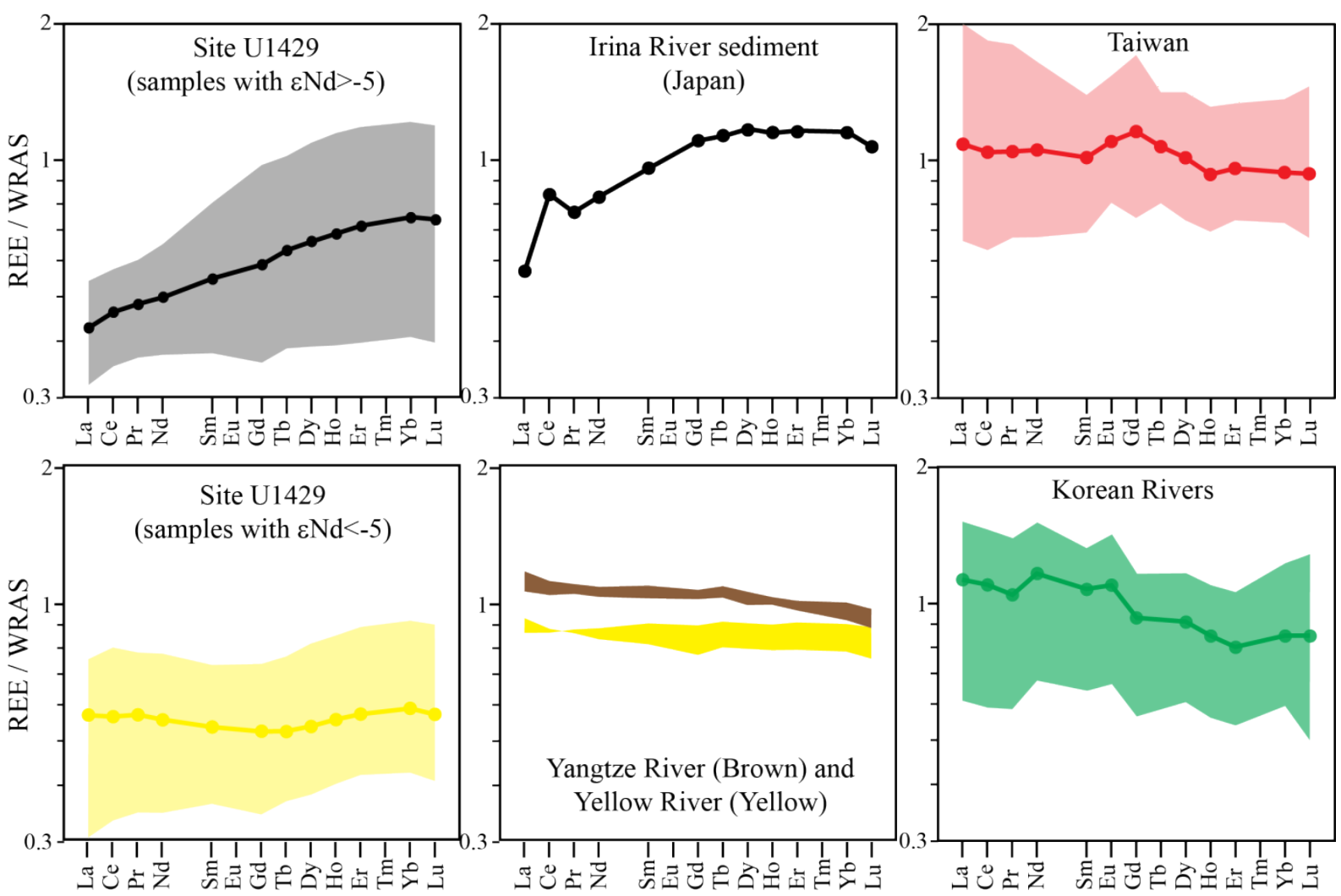

FIGURE 6: WRAS-normalized REE patterns at Site U1429 and the main potential sources

931 (Yellow and Yangtze rivers: Bayon et al., 2015; Korean rivers: Lee et al., 2003; Taiwan: Li et al., 2013; Irina river (Japan): this study. Colored envelopes denote the range of REE ratios. Lines and points indicate the average REE spectrum. Samples with radiogenic $\varepsilon_{\mathrm{Nd}}$ are characterized by REE compositions similar to the Irina river while samples with $\varepsilon_{\mathrm{Nd}}$ bellow -5 exhibit a composition similar to the Chinese rivers. 


\begin{tabular}{|c|c|c|c|c|c|c|c|c|c|c|c|c|c|c|c|c|}
\hline sample & $\begin{array}{c}\text { size } \\
\text { fraction } \\
(\mu \mathrm{m})\end{array}$ & $\begin{array}{l}143 \mathrm{Nd} / \\
144 \mathrm{Nd}\end{array}$ & $\begin{array}{c}2 \sigma \\
\left(10^{-6}\right)\end{array}$ & ENd & La & $\mathrm{Ce}$ & $\mathrm{Pr}$ & Nd & Sm & Gd & Tb & Dy & Ho & Er & $\mathrm{Yb}$ & Lu \\
\hline A1H1_117 & $<2$ & 0,512180 & 8 & $-8,9$ & 26,3 & 55,6 & 6,3 & 23,1 & 4,2 & 3,6 & 0,5 & 3,2 & 0,7 & 2,0 & 2,2 & 0,3 \\
\hline A1H2_119 & $<2$ & 0,512437 & 6 & $-3,9$ & & & & & & & & & & & & \\
\hline A7H6_119 & $<2$ & 0,512142 & 6 & $-9,7$ & 26,7 & 56,5 & 6,5 & 23,1 & 4,0 & 3,2 & 0,5 & 3,0 & 0,6 & 1,9 & 2,2 & 0,3 \\
\hline A7H6_70 & $<2$ & 0,512132 & 5 & $-9,9$ & 28,6 & 60,3 & 6,8 & 24,6 & 4,4 & 3,6 & 0,5 & 3,3 & 0,7 & 2,1 & 2,1 & 0,3 \\
\hline B2H3_119 & $<2$ & 0,512122 & 7 & $-10,1$ & 22,5 & 49,6 & 5,6 & 19,9 & 3,5 & 2,8 & 0,4 & 2,6 & 0,6 & 1,7 & 1,9 & 0,3 \\
\hline B2H4_8 & $<2$ & 0,512120 & 8 & $-10,1$ & 26,4 & 57,8 & 6,4 & 23,0 & 4,1 & 3,4 & 0,5 & 3,0 & 0,6 & 1,9 & 1,9 & 0,3 \\
\hline C10H3_118 & $<2$ & 0,512117 & 6 & $-10,2$ & 21,7 & 48,1 & 5,3 & 19,3 & 3,5 & 3,0 & 0,4 & 2,7 & 0,5 & 1,6 & 1,6 & 0,2 \\
\hline A1H1_117 & $2-30$ & 0,512259 & 8 & $-7,4$ & 26,4 & 59,0 & 6,7 & 25,1 & 4,7 & 4,3 & 0,7 & 4,1 & 0,8 & 2,5 & 2,5 & 0,4 \\
\hline A1H2_119 & $2-30$ & 0,512655 & 5 & 0,3 & 17,0 & 42,9 & 5,1 & 21,0 & 4,7 & 4,8 & 0,8 & 5,1 & 1,1 & 3,3 & 3,5 & 0,5 \\
\hline A7H6_119 & $2-30$ & 0,512140 & 8 & $-9,7$ & 30,6 & 71,1 & 7,8 & 29,0 & 5,3 & 4,4 & 0,7 & 4,1 & 0,8 & 2,4 & 2,4 & 0,3 \\
\hline A7H6_70 & $2-30$ & 0,512154 & 8 & $-9,4$ & 27,0 & 59,2 & 6,7 & 24,6 & 4,5 & 3,8 & 0,6 & 3,5 & 0,7 & 2,1 & 2,1 & 0,3 \\
\hline B2H3_119 & $2-30$ & 0,512095 & 4 & $-10,6$ & 27,7 & 61,9 & 6,9 & 25,0 & 4,4 & 3,7 & 0,5 & 3,4 & 0,7 & 2,0 & 2,1 & 0,3 \\
\hline B2H4_8 & $2-30$ & 0,512112 & 6 & $-10,3$ & 26,9 & 59,9 & 6,6 & 24,1 & 4,4 & 3,7 & 0,6 & 3,4 & 0,7 & 2,0 & 2,0 & 0,3 \\
\hline C1OH2_119 & $2-30$ & 0,512094 & 5 & $-10,6$ & 14,0 & 31,9 & 3,6 & 13,6 & 2,5 & 2,2 & 0,3 & 2,0 & 0,4 & 1,2 & 1,2 & 0,2 \\
\hline C10H3_118 & $2-30$ & 0,512134 & 9 & $-9,8$ & 26,9 & 59,8 & 6,6 & 24,2 & 4,4 & 3,9 & 0,6 & 3,5 & 0,7 & 2,1 & 2,0 & 0,3 \\
\hline A1H1_117 & $30-63$ & 0,512648 & 5 & 0,2 & 17,4 & 41,7 & 5,0 & 20,2 & 4,6 & 4,6 & 0,7 & 4,8 & 1,0 & 3,1 & 3,2 & 0,5 \\
\hline A1H2_119 & $30-63$ & 0,512722 & 4 & 1,6 & 16,5 & 42,3 & 5,2 & 21,4 & 4,9 & 5,1 & 0,8 & 5,4 & 1,2 & 3,5 & 3,7 & 0,5 \\
\hline A7H6_119 & $30-63$ & 0,512520 & 4 & $-2,3$ & 27,1 & 68,5 & 7,5 & 26,7 & 5,1 & 4,0 & 0,6 & 3,7 & 0,8 & 2,4 & 2,6 & 0,4 \\
\hline A7H6_70 & $30-63$ & 0,512499 & 5 & $-2,7$ & & & & & & & & & & & & \\
\hline B2H3_119 & $30-63$ & 0,512313 & 6 & $-6,3$ & & & & & & & & & & & & \\
\hline B2H4_8 & $30-63$ & 0,512263 & 9 & $-7,3$ & 14,6 & 31,5 & 3,5 & 13,2 & 2,5 & 2,4 & 0,4 & 2,2 & 0,5 & 1,4 & 1,3 & 0,2 \\
\hline C1OH2_119 & $30-63$ & 0,512163 & 7 & $-9,3$ & & & & & & & & & & & & \\
\hline C10H3_118 & $30-63$ & 0,512117 & 8 & $-10,2$ & 15,1 & 32,8 & 3,7 & 14,0 & 2,7 & 2,5 & 0,4 & 2,2 & 0,5 & 1,3 & 1,3 & 0,2 \\
\hline A1H1_117 & $0-63$ & 0,512268 & 7 & $-7,2$ & 24,6 & 54,6 & 6,1 & 23,1 & 4,4 & 4,0 & 0,6 & 3,7 & 0,8 & 2,3 & 2,4 & 0,3 \\
\hline A7H6_70 & $0-63$ & 0,512148 & 8 & $-9,6$ & 26,5 & 57,3 & 6,5 & 23,8 & 4,3 & 3,7 & 0,5 & 3,3 & 0,7 & 2,1 & 2,0 & 0,3 \\
\hline B2H4_8 & $0-63$ & 0,512122 & 9 & $-10,1$ & 23,9 & 52,5 & 5,8 & 21,2 & 3,8 & 3,3 & 0,5 & 2,9 & 0,6 & 1,7 & 1,8 & 0,3 \\
\hline C1OH3_118 & $0-63$ & 0,512499 & 5 & $-2,7$ & 23,6 & 52,6 & 5,9 & 21,4 & 4,0 & 3,4 & 0,5 & 3,1 & 0,6 & 1,8 & 1,8 & 0,3 \\
\hline
\end{tabular}

940 TABLE 1: Nd isotopes and REE compositions (ppm) of the test samples from Site U1429. 


\begin{tabular}{|c|c|c|c|c|c|c|c|c|c|c|c|c|c|c|c|c|c|}
\hline sample & age (ka) & $\begin{array}{l}143 \mathrm{Nd} / \\
144 \mathrm{Nd}\end{array}$ & $\begin{array}{c}2 \sigma \\
\left(10^{-6}\right)\end{array}$ & $\mathrm{eNd}$ & $(\mathrm{Nd} / \mathrm{Yb}) \mathrm{N}$ & La & Ce & Pr & $\mathrm{Nd}$ & Sm & Gd & Tb & Dy & Ho & Er & $\mathrm{Yb}$ & Lu \\
\hline \multicolumn{18}{|c|}{$0-2 \mu \mathrm{m}$ size fraction } \\
\hline H1_5 & 0,2 & 0,512128 & 7 & $-10,0$ & 0,83 & 44,5 & 39,8 & 4,6 & 16,4 & 2,9 & 2,3 & 0,4 & 2,3 & 0,5 & 1,6 & 1,8 & 0,3 \\
\hline A1H1_117 & 3,7 & 0,512180 & 8 & $-8,8$ & 0,99 & 26,3 & 55,6 & 6,3 & 23,1 & 4,1 & 3,6 & 0,5 & 3,2 & 0,7 & 2,0 & 2,2 & 0,3 \\
\hline A1H3_119 & 11,1 & ,512186 & 7 & $-8,8$ & 0,91 & 28,0 & 50,4 & 5,7 & 20,4 & 3,6 & 3,1 & 0,5 & 2,9 & 0,6 & 1,9 & 2,1 & 0,3 \\
\hline B2H3_119 & 16,0 & 0,512122 & 7 & $-10,1$ & 0,97 & 22,5 & 49,6 & 5,6 & 19,9 & 3,5 & 2,8 & 0,4 & 2,6 & 0,6 & 1,7 & 1,9 & 0,3 \\
\hline B2H4_8 & 16,7 & 0,512120 & 8 & $-10,0$ & 1,09 & 26,4 & 57,8 & 6,4 & 23,0 & 4,1 & 3,4 & 0,5 & 3,0 & 0,6 & 1,9 & 1,9 & 0,3 \\
\hline A2H6_119 & 28,5 & & & & 0,96 & 26,7 & 56,8 & 6,2 & 22,2 & 3,9 & 2,8 & 0,5 & 3,2 & 0,7 & 2,0 & 2,1 & 0,3 \\
\hline B4H6_119 & 52,3 & 0,512164 & 9 & $-9,2$ & 0,95 & 24,9 & 53,9 & 5,9 & 21,3 & 3,8 & 2,8 & 0,5 & 3,0 & 0,6 & 1,9 & 2,1 & 0,3 \\
\hline B5H3_118 & 63,4 & 0,512166 & 6 & $-9,2$ & 1,03 & 27,4 & 51,4 & 5,7 & 20,5 & 3,7 & 3,1 & 0,5 & 2,8 & 0,6 & 1,7 & 1,8 & 0,3 \\
\hline${ }^{B 5} \mathrm{H}_{-} 7$ & 71,2 & 0,512149 & 7 & $-9,5$ & 0,99 & 22,4 & 44,3 & 4,9 & 17,4 & 3,0 & 2,5 & 0,4 & 2,4 & 0,5 & 1,5 & 1,6 & 0,2 \\
\hline B6H2_119 & 81,9 & 512244 & 6 & $-7,7$ & 0,90 & 21,7 & 42,6 & 4,8 & 17,4 & 3,1 & 2,6 & 0, & 2,5 & 0,5 & 1,7 & 1,8 & 0,3 \\
\hline C8H1_9 & 93,8 & 0,512221 & 6 & $-8,1$ & 0,95 & 24,2 & 47,4 & 5,4 & 19,8 & 3,5 & 3,0 & 0,5 & 2,8 & 0,6 & 1,8 & 1,9 & 0,3 \\
\hline A7H4_110 & 111,2 & 0,512135 & 5 & $-9,8$ & 0,96 & 25,1 & 48,8 & 5,5 & 19,6 & 3,3 & 2,7 & 0,4 & 2,6 & 0,6 & 1,8 & 1,9 & 0,3 \\
\hline A7H6_70 & 120,8 & 32 & 5 & $-9,9$ & & 28,6 & 60,3 & 6,8 & 24,6 & 4,3 & 3,6 & 0 & & 0,7 & 2,1 & 2,1 & 0,3 \\
\hline A7H6_119 & 122,8 & 0,512142 & 6 & $-9,7$ & 0,99 & 26,7 & 56,5 & 6,5 & 23,1 & 4,0 & 3,2 & 0,5 & 3,0 & 0,6 & 1,9 & 2,2 & 0,3 \\
\hline B8H3_1 & 128,7 & 512164 & 6 & $-9,2$ & 0,98 & 18,1 & 34,0 & 3,9 & 13,8 & 2,4 & 2,0 & 0,3 & 1,9 & 0,4 & 1,3 & 1,3 & 0,2 \\
\hline B8H4_119 & 132,9 & 0,512206 & 5 & $-8,4$ & & 23,6 & 44,6 & 5,0 & 18,1 & 3,2 & 2,7 & 0,4 & 2,5 & 0,5 & 1,6 & 1,7 & 0,3 \\
\hline B8H6_7 & 138,7 & 0,512322 & 4 & $-6,1$ & 0,98 & 21,0 & 41,8 & 4,8 & 17,4 & 3,2 & 2,7 & 0,4 & 2,5 & 0,5 & 1,6 & 1,6 & 0,2 \\
\hline C10H2_119 & 140,1 & & & & 1,1 & 27,3 & 62,5 & 6,9 & 25,4 & 4,5 & 3,8 & 0,6 & 3,5 & 0,7 & 2,0 & 2,0 & 0,3 \\
\hline C1OH3_118 & 142,6 & 0,512117 & 6 & $-9,8$ & 1,10 & 21,7 & 48,1 & 5,3 & 19,3 & 3,4 & 3,0 & 0,4 & 2,7 & 0,5 & 1,6 & 1,6 & 0,2 \\
\hline B1OH3_119 & 162,8 & 0,512127 & 6 & $-10,0$ & 1,00 & 25,0 & 51,3 & 5,7 & 20,2 & 3,6 & 2,9 & 0,4 & 2,7 & 0,6 & 1,8 & 1,9 & 0,3 \\
\hline B1OH4_118 & 165,5 & 12105 & 6 & $-9,6$ & & 24,4 & 48,7 & 5,4 & 19,4 & 3,4 & 2,8 & 0,4 & 2,7 & 6 & .7 & 1,8 & 0,3 \\
\hline $\mathrm{A} 10 \mathrm{H} 3 \_8$ & 167,3 & 0,512126 & 7 & $-10,0$ & 0,94 & 23,1 & 45,0 & 5,1 & 18,0 & 3,1 & 2,5 & 0,4 & 2,5 & 0,5 & 1,7 & 1,8 & 0,3 \\
\hline A10H3_119 & 169,3 & 0,512191 & 4 & $-8,7$ & & & & & & & & & & & & & \\
\hline & 178 & & 3 & $-8,5$ & & 24,2 & 7,4 & 5,4 & 19,1 & 3,3 & 2,7 & 0, & & 6 & 1,7 & 1,8 & J,3 \\
\hline B11H3_119 & 181,9 & 0,512194 & 5 & $-8,7$ & 1,00 & 26,7 & 56,0 & 6,2 & 22,1 & 3,8 & 3,2 & 0,5 & 2,9 & 0,6 & 1,9 & 2,0 & 0,3 \\
\hline $1+15$ & 185,3 & 0,512143 & 7 & $-9,7$ & 0,8 & 21,8 & 37,0 & 4,3 & 15,0 & 2,6 & 2,1 & 0,3 & 21 & 0,5 & 1,4 & 1,6 & 0,2 \\
\hline B11H6_9 & 192,6 & 12163 & 6 & $-9,3$ & & 23,3 & 45,3 & 5,1 & 18,4 & 3,2 & 2,6 & 0,4 & 2,5 & 5 & 1,7 & 1,7 & 0,3 \\
\hline B11H6_119 & 195,3 & 0,512175 & 7 & $-9,0$ & 0,9 & 25,2 & 49,4 & 5,6 & 20,1 & 3,5 & 2,9 & 0,4 & 2,8 & 0,6 & 1,8 & 1,9 & 0,3 \\
\hline & 202 & & 5 & -87 & & 27,0 & 53,6 & 6,3 & 22,9 & 4,2 & 3,7 & 0 & 3,4 & 7 & 2,1 & 2,2 & 0,3 \\
\hline 13H5_119 & 205,2 & 112200 & 4 & $-8,6$ & & 23,6 & 46,2 & 5,3 & 19,2 & 3,5 & 2,9 & 0,4 & 2,8 & 0 & 1,8 & 1,9 & 0,3 \\
\hline $\mathrm{A}_{12 \mathrm{H}}{ }_{3} 119$ & 217,4 & 0,51220 & 7 & $-8,5$ & 0,92 & 21,0 & 39,8 & 4,5 & 16,3 & 2,9 & 2,4 & 0,4 & 2,3 & 0,5 & 1,5 & 1,6 & 0,2 \\
\hline A12H5_118 & 224,0 & 0, & 5 & $-8,9$ & & 25,1 & 49,3 & 5,6 & 19,8 & 3,4 & 2,9 & 0 & 2,8 & 6 & 1,8 & 1,9 & 0,3 \\
\hline B13H7_9 & 234,8 & 112205 & 6 & $-8,5$ & 0,9 & 23,7 & 45,5 & 5,2 & 18,6 & 3,2 & 2,7 & 0,4 & 2,5 & 0,5 & 1,6 & 1,8 & 0,3 \\
\hline B16 & 25 & 0 , & 6 & $-10,3$ & 0,9 & 24,0 & 47,3 & 5,4 & 19,1 & 3,4 & 2,7 & 0 & 2,6 & 0,6 & 1,7 & 1,8 & 0,3 \\
\hline B16H5_119 & 262,5 & 0, & 5 & $-10,6$ & 1,0 & 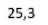 & 47,1 & 5,4 & 18,8 & 3,1 & 2,5 & 0 & 2,4 & 0,5 & 1,6 & 1,7 & 0,3 \\
\hline 5_118 & 27 & 0 & 5 & $-9,5$ & 1,0 & 25,4 & 50,6 & 5,8 & 20,6 & 3,6 & 3,0 & 0 & 2,8 & 0,6 & 1,8 & 1,8 & 0,3 \\
\hline 2-119 & 277 & 0 & 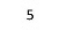 & -9 & 1,0 & 25,4 & 49,6 & 5,6 & 20,4 & 3,6 & 3,0 & 0,5 & 2,8 & 6 & 1,8 & 1,9 & 0,3 \\
\hline 118 & 28 & 512153 & 6 & $-9,5$ & 1,0 & 27 & 53,7 & 6,1 & 22,0 & 3,9 & 3 & 0,5 & 3,1 & 0,7 & 2,0 & 2,0 & 0,3 \\
\hline & 28 & & 5 & -8 & & 1 & 52,1 & 6,0 & 22,2 & 4,1 & 3,7 & 0,6 & 3,4 & 0,7 & 2,1 & 2,2 & 0,3 \\
\hline & 300 & 0 & 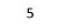 & $-9,5$ & 1,04 & 26,3 & 53,0 & 6,0 & 22,2 & 4,0 & 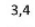 & 0,5 & 3,1 & 0,7 & 1,9 & 2,0 & 0,3 \\
\hline B18H3_119 & 310,3 & & & & & & 51,1 & 5,8 & 20,7 & 3,8 & 3,1 & 0,5 & & & 1,8 & 18 & 0.3 \\
\hline & 33 & & 3 & & & 24,2 & 49,7 & 5,6 & 20,1 & 3,6 & 3,0 & 0,5 & 2,7 & 0,6 & 1,7 & 1,7 & 0,2 \\
\hline $\mathrm{A} 2 \mathrm{OH} 2 \mathrm{H}_{2} 119$ & 359,2 & 512092 & 7 & $-10,7$ & 1,1 & 26,5 & 54,5 & 6,1 & 21,8 & 3,9 & 3,1 & 0,5 & 2,9 & 0,6 & 1,8 & 8 & 0,3 \\
\hline & & & 1 & & & & 16 & 5,8 & 21,1 & 3,9 & 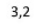 & & & & 8 & 18 & 0,3 \\
\hline $\mathrm{A} 2 \mathrm{OH}$ & 369 & 0 & 5 & $-10,0$ & 1,0 & 25 & 51,6 & 5,8 & 21 & 3,8 & & & 3,0 & 0,0 & 1,8 & 1,9 & 0,3 \\
\hline B2OH3_119 & 37 & $=0$ & 5 & $-10,0$ & & & & & & & & & & & & & \\
\hline & & & 6 & & , & & 49 & $5,7, \quad-$ & 20,7 & 3,8 & 3,2 & 0,5 & 3,0 & 0,6 & 1,9 & 2,0 & 0,3, \\
\hline
\end{tabular}

\begin{tabular}{|c|c|c|c|c|c|c|c|c|c|c|c|c|c|c|c|c|c|}
\hline sample & age & $\begin{array}{c}143 \mathrm{Nd} / \\
144 \mathrm{Nd} \\
\end{array}$ & $\begin{array}{c}2 \sigma \\
\left(10^{-6}\right) \\
\end{array}$ & sNd & $(\mathrm{Nd} / \mathrm{Yb}) \mathrm{N}$ & La & $\mathrm{Ce}$ & Pr & Nd & Sm & Gd & Tb & Dy & Ho & Er & $\mathrm{Yb}$ & Lu \\
\hline \multicolumn{18}{|c|}{$\overline{30-63 \mu \mathrm{m} \text { size fraction }}$} \\
\hline A1 & 3,7 & & 5 & 0,3 & 58 & 17,4 & 41,7 & 5,0 & 20,2 & 4,5 & 4,6 & 0,7 & 4,8 & 1,0 & , & 3,2 & \\
\hline $\mathrm{A}^{\mathrm{H} \mathrm{H}_{2}} \mathrm{I}$ & 8,1 & & 4 & $-3,9$ & 5 & 16,5 & 2,3 & 5,2 & 21,4 & 4,9 & 5,1 & 0,8 & 5,4 & 1,2 & 3,5 & 3,7 & 0,5 \\
\hline $\mathrm{AlH}_{3}$ & 11,1 & 12230 & 9 & $-5,6$ & 0 & 18,4 & 38,1 & 4,3 & 16,2 & 3,2 & 2,6 & 0,5 & 2,9 & 0,6 & 1,9 & 2,0 & 0,3 \\
\hline B2 & 16,0 & 0 & & . & & & & & & & & & & & & & \\
\hline $\mathrm{H}_{4}$ & 16,7 & 3 & 9 & $-7,2$ & 50 & 14,6 & 31,5 & 3,5 & 13,2 & 2,5 & 2,4 & 0,4 & 2,2 & 0,5 & 1,4 & 1,3 & 0, \\
\hline A2 2 & 28,5 & 30 & 9 & $-7,9$ & 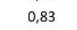 & 14,2 & 28,6 & 3,2 & 12,0 & 2,3 & 1,9 & 0,3 & 2,0 & 0,4 & 1,3 & 1,3 & 0,2 \\
\hline B & 52,3 & & 10 & $-5,0$ & & 15,6 & 27,7 & 3,2 & 12,4 & 2,4 & 2,0 & 0,3 & 2,1 & 0,4 & 1,4 & 1,5 & 0,2 \\
\hline Bs & 6 & & 8 & 3,4 & & 17,5 & 36,3 & 4,2 & 16,1 & 3,1 & 2,6 & 0,4 & 2,7 & 0,6 & 1,7 & 1,8 & 0,3 \\
\hline H6_7 & 71,2 & 0 & 7 & $-2,7$ & 73 & 17,6 & 37,8 & 4,4 & 17,0 & 3,5 & 3,0 & 0,5 & 3,2 & 0,7 & 2,0 & 2,2 & 0,3 \\
\hline $12 \_119$ & & & 9 & $-0,8$ & & & 45,3 & 5,3 & 20,2 & 4,1 & 3,5 & 0,6 & 3,8 & 0,8 & 2,5 & 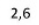 & 0,4 \\
\hline 08 & 93,8 & & 9 & $-1,4$ & 56 & 19,5 & 44,9 & 5,4 & 1,5 & 4,9 & 4,8 & 0,8 & 5,3 & 1,1 & 3,4 & 3,6 & 0,5 \\
\hline A7H4_110 & 111,2 & 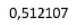 & 13 & $-10,3$ & 0,99 & 26,0 & 35,5 & 4,1 & 15,7 & 2,8 & 2,3 & 0,4 & 2,3 & 0,5 & 1,4 & 1,5 & 0,2 \\
\hline A7HG & & & 5 & $-2,7$ & & & & & & & & & & & & & \\
\hline A7 & 1 & ( & 4 & $-2,3$ & & 27,1 & 68,5 & 7,5 & 26,7 & 4,7 & 4,0 & 0,6 & 3,7 & 0,8 & 2,4 & 2,6 & 0,4 \\
\hline B\& & & & & $-2,5$ & & 16,9 & 36,6 & 4,3 & 16 & 3,3 & 2,9 & 0,5 & 2,9 & 0,6 & 1,8 & 1,8 & 0,3 \\
\hline & & & 6 & -8 & & & 30,8 & 3,7 & 1,1 & 2,8 & 2,3 & 0,4 & 2,3 & 0,5 & 1,4 & 1,5 & 0,2 \\
\hline $\mathrm{ClOH}_{-}$ & 1 & 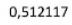 & 8 & $-9,3$ & .01 & 15,1 & 2,8 & 3,7 & 14,0 & 2,7 & 2,5 & 0,4 & 2,2 & 0,5 & 1,3 & 1,3 & 0,2 \\
\hline & & & & $-2,7$ & & & 27,2 & 3,2 & & 2,3 & & & & & & & 0,2 \\
\hline B1 & & & 9 & -8, & & 3 & 27,3 & 3,2 & 9 & 2,2 & 1,8 & 0,3 & 2,0 & 0,4 & 1,3 & 1,3 & 0,2 \\
\hline 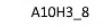 & the & 0,512173 & 7 & $-9,0$ & 89 & 20,1 & 44,4 & 5,0 & 18,4 & 3,3 & 2,4 & 0,4 & 2,8 & 0,6 & 1, & 1,9 & 0,3 \\
\hline & & & & & & & & 4,0 & & 3 & & & & & & & 0,3 \\
\hline B1 & 1 & ( & 8 & $-6,3$ & & 12,1 & 7,0 & 3,1 & 0 & 2,4 & 0 & 0,3 & 2,2 & 5 & 1,3 & 1,4 & 0,2 \\
\hline B11 & 1 & 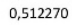 & 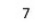 & $-7,1$ & & 14,7 & 33,0 & 3,8 & 14,5 & 2,9 & 2,3 & 0,4 & 2,5 & 0 , & 1,6 & 1,6 & 0,2 \\
\hline & & & & & & & & 1 & & 2 & & 0,3 & 2 & 0 & & & 0,2 \\
\hline$B$ & 1 & 158 & 11 & -7 & & 15,1 & 4,9 & 4,0 & 2 & 2,9 & 4 & 0,4 & 2,6 & 0,5 & 1,6 & 1,7 & 0,3 \\
\hline B11 & & & 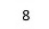 & -6, & & 0 & 34,4 & 4,0 & 5,1 & 3,0 & 2,5 & 4 & 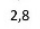 & 0,6 & 1,8 & 18 & 0,3 \\
\hline & & & & -7 & & & 1 & 4 & & 3, & 3, & 0 & 4 & 0 & & 2 & 0,4 \\
\hline $\mathrm{C} 1$ & 2 & & 5 & 0,3 & & 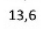 & 34,7 & 4,2 & 3 & 4,0 & 4,0 & 0,7 & 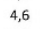 & 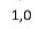 & 3,1 & 3,2 & 0,5 \\
\hline & & & & -34 & & & 29,6 & 3,4 & & 2,6 & 2,2 & 04 & 2,6 & 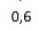 & 1 & 8 & 0,3 \\
\hline & & & & -7 & & & 31,1 & 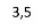 & & 2 & 1, & 0 & 2, & 0, & 1 & 1 & 0,2 \\
\hline & & & & -3 & & & 4 & 4,0 & & 2,6 & 2,1 & 0,4 & 2,4 & 0, & 1,6 & 1,9 & 0,3 \\
\hline & & & & -10 & & & 32,3 & 3,7 & 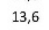 & 2,5 & 19 & . & -3 & 0, & 1,4 & 4 & 0,2 \\
\hline & & & & -5 & & & 40,5 & 4,7 & & 3,4 & 2,7 & 0, & 2,9 & 0, & 1 & 1 & 0,3 \\
\hline & & & & -8 & & & & 4,8 & & 3,2 & 2,6 & 0,4 & 2,7 & 0 & 1,8 & 1,8 & 0,3 \\
\hline & & & & $-7,8$ & & & 43,7 & 5,0 & 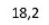 & 3 & 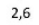 & 0,5 & 2,8 & 5 & 1,8 & 1,9 & 0,3 \\
\hline & & & & -6 & & & & & & 3, & & 0 & & & & & \\
\hline & 3 & & 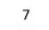 & 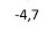 & & & & 4,2 &, 7 & 3,2 & 2,7 & 0,5 & 3,0 & 7 & 2,0 & 2,2 & 0,3 \\
\hline & 3 & & & & & & 7,1 & 4,3 & 16,1 & 3,1 & 2, & 0,4 & 2,7 & 0,6 & 1,7 & 1,8 & 0,3 \\
\hline & & & 7 & 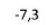 & & & 4,9 & 4,0 & & & 2 & 0 & 2 & 0 & 1 & & \\
\hline & & & & -10 & & & & 4,3 & 1 & 2,9 & 2.2 & 0 & 2,2 & 0,5 & 1,3 & 1,3 & 0,2 \\
\hline & & & & 95 & & & & 4,5 & & 3 & 2 & 0 & 2. & 0, & 1. & 1 & \\
\hline & & & 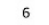 & -9 & & & & 5,1 & & 3,6 & 26 & 0 & 2,8 & 0 & 1,8 & 1 & \\
\hline & & & & -9, & & & 17 & 4,7 & 17,4 & 33 & 2,6 & & 27 & 0,6 & 1,7 & 1,7 & 0,3 \\
\hline & & & & & & & 33.2 & 38 & 14,2 & 27 & 2,1 & 0.4 & 24 & 0.5 & 1.6 & 1. & \\
\hline
\end{tabular}

944 TABLE 2: $\varepsilon_{\mathrm{Nd}}$ and REEs of the Site U1429 sediments. 


\begin{tabular}{|c|c|c|c|c|c|}
\hline region & $\begin{array}{l}\mathrm{ENd} \\
\text { (min) }\end{array}$ & $\begin{array}{l}\varepsilon N d \\
(\max )\end{array}$ & sample type & $\begin{array}{c}\text { nombre of } \\
\text { samples }\end{array}$ & references \\
\hline Honchu Hokkaido & 5,0 & 6,0 & not precised & not given & $\begin{array}{c}\text { Mahoney and references } \\
\text { therein, } 2005\end{array}$ \\
\hline Kyushu Shikoku & $-6,0$ & 4,0 & not precised & not given & $\begin{array}{c}\text { Mahoney and references } \\
\text { therein, } 2005\end{array}$ \\
\hline $\begin{array}{c}\text { Southern Japanese } \\
\text { volcanos }\end{array}$ & $-6,0$ & $-4,0$ & volcanos & $>39$ & $\begin{array}{l}\text { Ishizaka and Carlson, 1983, } \\
\text { Chen et al., 1993; Mahoney } \\
\text { and references therein, } 2005\end{array}$ \\
\hline Kagoshima River & 2,0 & 2,0 & river sediment & 1 & this study \\
\hline Taïwan & $-15,0$ & $-10,0$ & not precised & 55 & $\begin{array}{c}\text { Chen et al., } 1990 \text {; John et al., } \\
1990\end{array}$ \\
\hline Yangtze River (mouth) & $-13,0$ & $-10,5$ & river sediment & 18 & $\begin{array}{l}\text { Goldstein et al., } 1984 \text {; Yang et } \\
\text { al., 2007; Bayon et al., } 2015\end{array}$ \\
\hline Yellow River (mouth) & $-12,6$ & $-10,9$ & river sediment & 4 & $\begin{array}{l}\text { Goldstein et al., } 1984 \text {; Yang et } \\
\text { al., 2007; Bayon et al., } 2015\end{array}$ \\
\hline $\begin{array}{l}\text { Yellow River (all } \\
\text { reaches) }\end{array}$ & $-13,9$ & $-9,6$ & river sediment & not given & $\begin{array}{c}\text { Hu et al., } 2012 \text { and references } \\
\text { therein }\end{array}$ \\
\hline Korean rivers & $-27,5$ & $-13,1$ & river sediment & 8 & Lan et al., 1995 \\
\hline $\begin{array}{l}\text { Korean cristaline } \\
\text { massif }\end{array}$ & $-33,6$ & $-4,5$ & crystaline massif & 58 & Lan et al., 1995; Lee et al., 2002 \\
\hline North Tianshan & $-6,6$ & $-5,2$ & quaternary loess & $>5$ & $\begin{array}{c}\text { Liu et al., } 1994 \text { and references } \\
\text { therein }\end{array}$ \\
\hline SW Tarim Basin & $-12,8$ & $-9,1$ & quaternary loess & $>11$ & $\begin{array}{c}\text { Liu et al., } 1994 \text { and references } \\
\text { therein }\end{array}$ \\
\hline NE China & $-9,6$ & $-8,5$ & quaternary loess & $>2$ & $\begin{array}{c}\text { Liu et al., } 1994 \text { and references } \\
\text { therein }\end{array}$ \\
\hline Ordos Plateau & $-21,0$ & $-10,0$ & quaternary loess & not given & $\begin{array}{c}\text { Chen et al., 2007; Sun et al., } \\
\text { 2008, Hu et al., } 2012\end{array}$ \\
\hline Central Loes Plateau & $-12,0$ & $-7,0$ & quaternary loess & not given & $\begin{array}{l}\text { Chen et al., 2007; Sun et al., } \\
\text { 2008, Hu et al., } 2012\end{array}$ \\
\hline Nanjing & $-12,2$ & $-10,9$ & quaternary loess & not given & $\begin{array}{c}\text { Liu et al., } 1994 \text { and references } \\
\text { therein }\end{array}$ \\
\hline
\end{tabular}

948 TABLE 3: $\varepsilon_{\mathrm{Nd}}$ of the main potential sediment sources for Site U1429. 


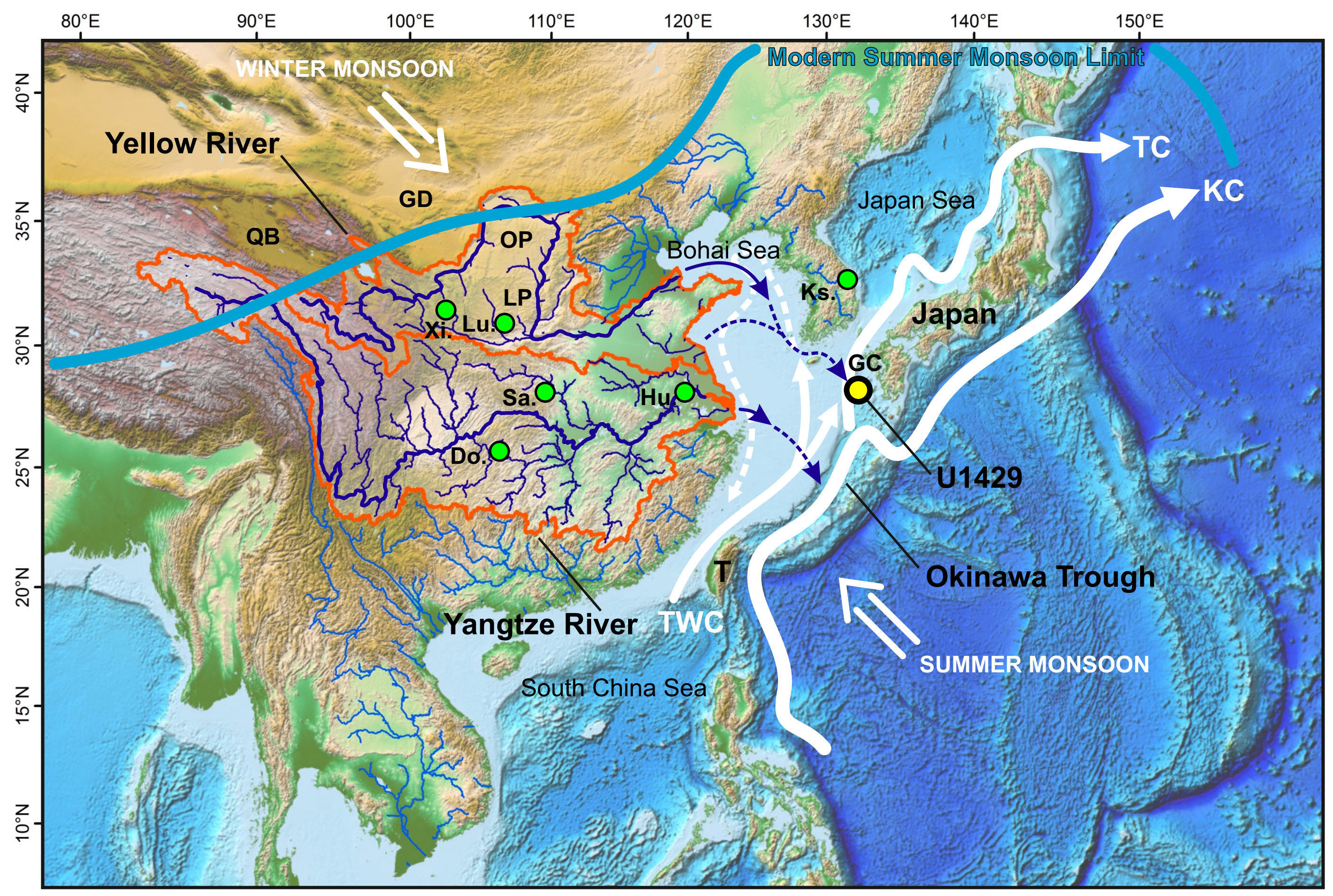




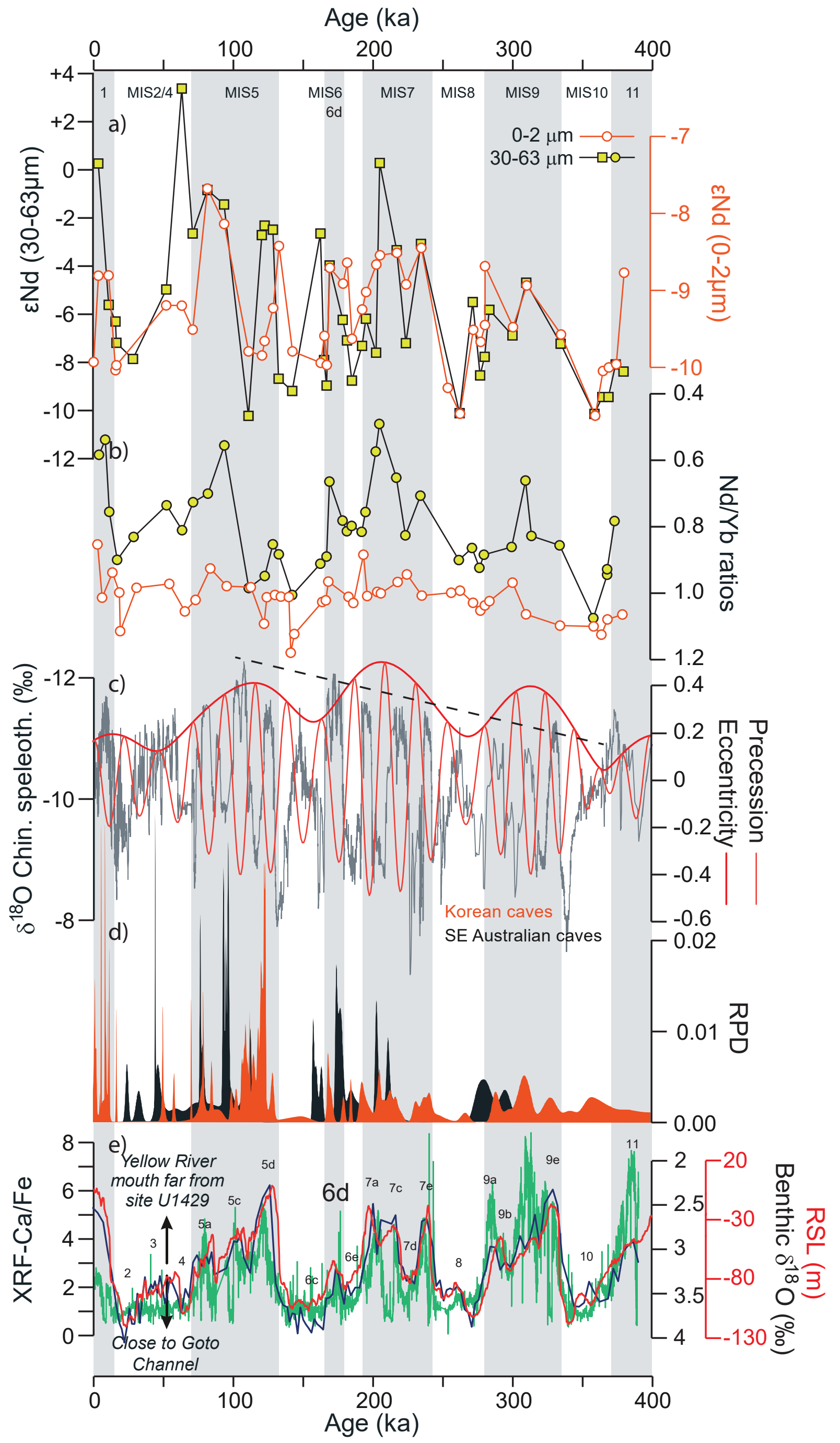

Figure 2 


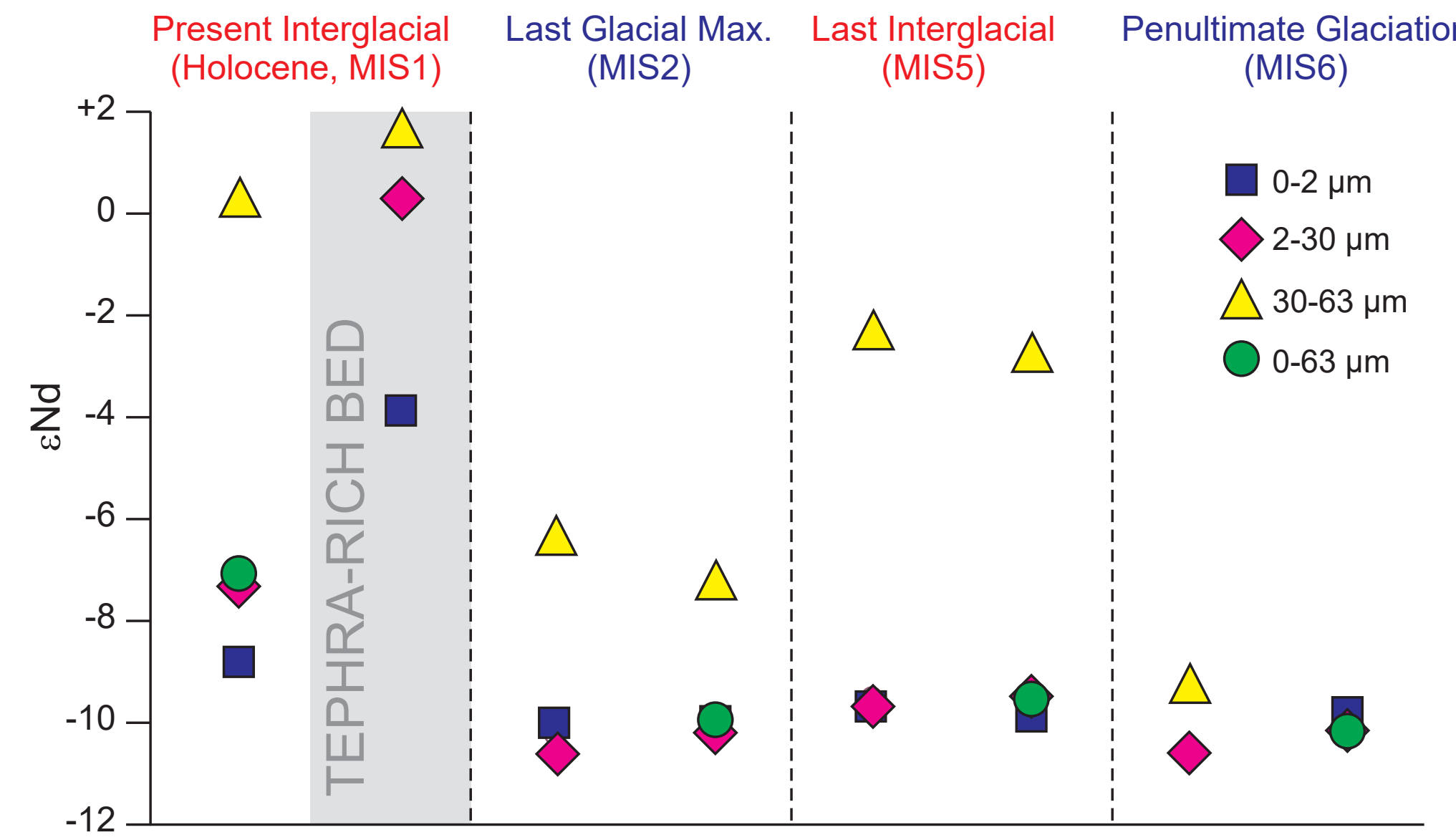

Figure 3 


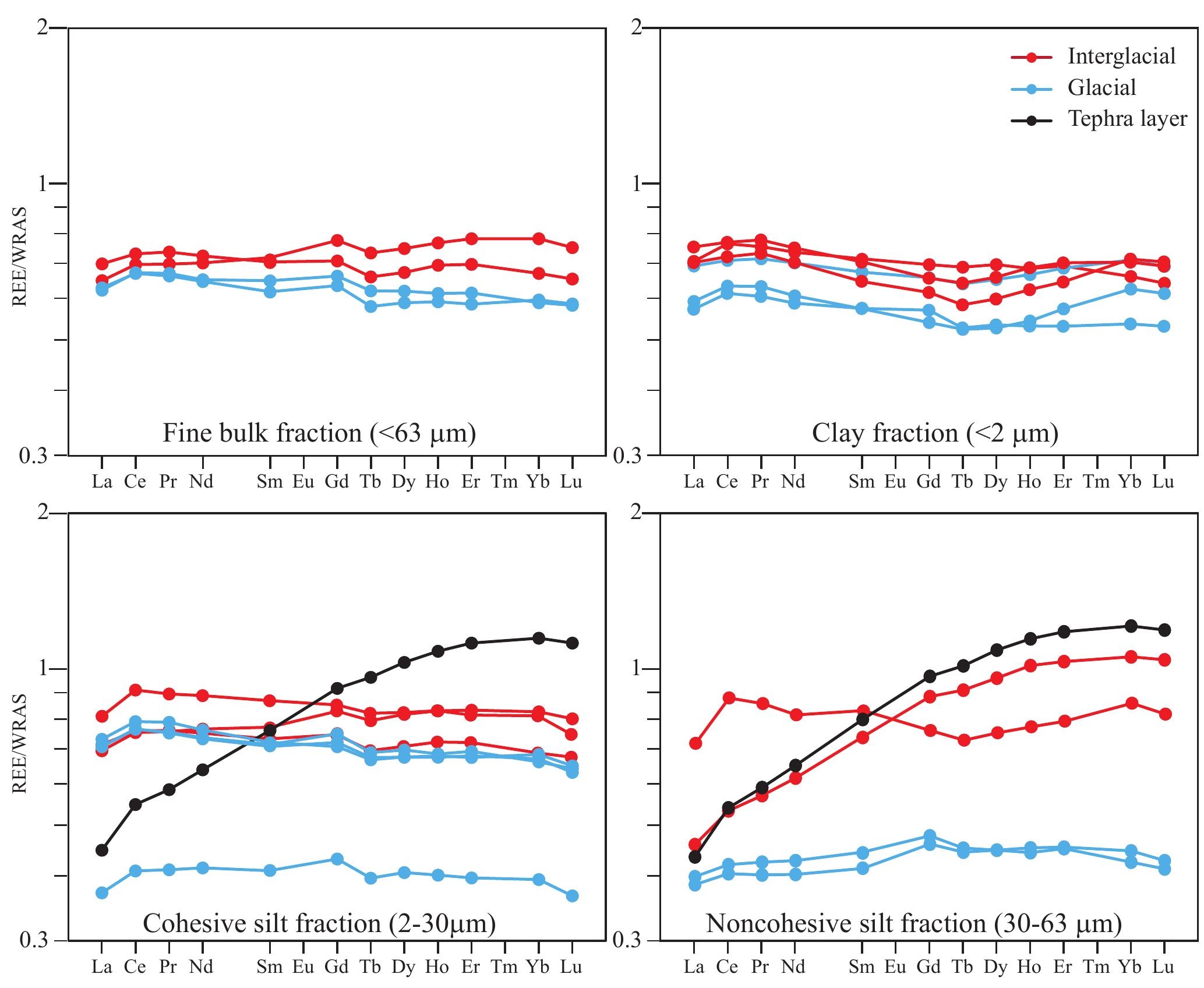

Figure 4 


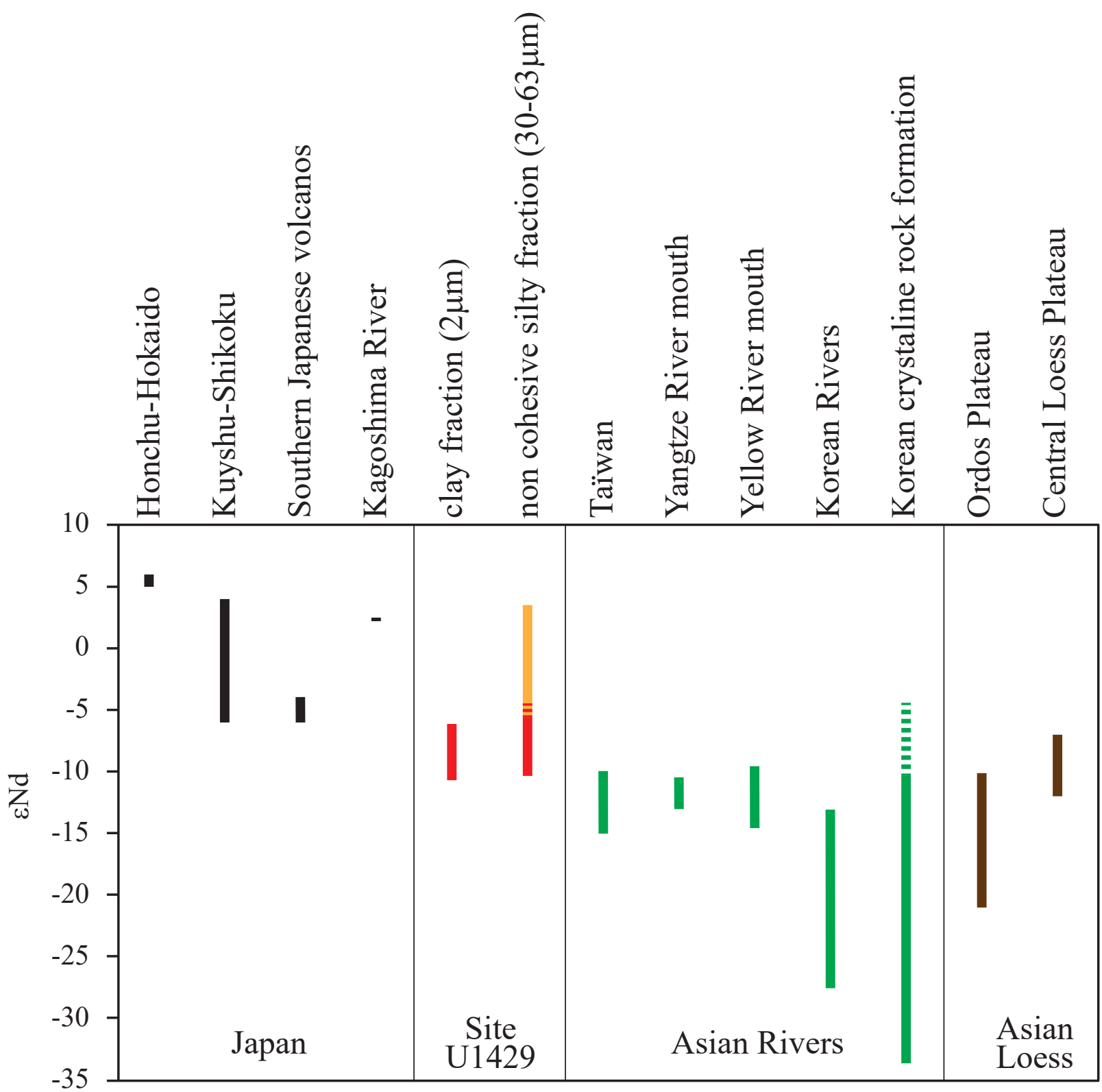

Figure 5 

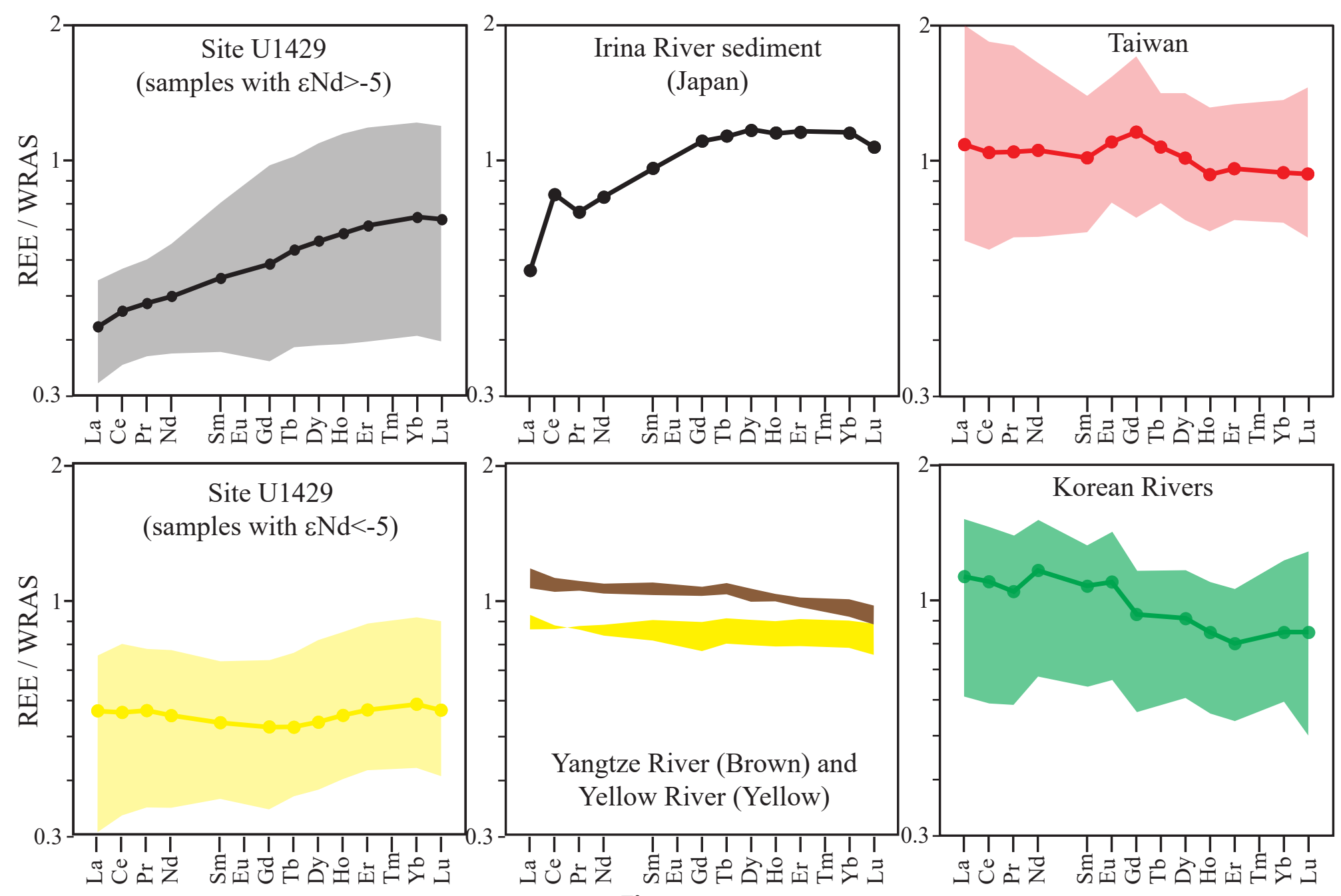

\section{Figure 6}


Table 1

\begin{tabular}{|c|c|c|c|c|c|c|c|c|c|c|c|c|c|c|c|c|}
\hline sample & $\begin{array}{c}\text { size } \\
\text { fraction } \\
(\mu \mathrm{m})\end{array}$ & $\begin{array}{l}143 \mathrm{Nd} / \\
144 \mathrm{Nd}\end{array}$ & $\begin{array}{c}2 \sigma \\
\left(10^{-6}\right)\end{array}$ & $\varepsilon N d$ & La & $\mathrm{Ce}$ & $\mathrm{Pr}$ & Nd & Sm & Gd & Tb & Dy & Ho & $\mathrm{Er}$ & $\mathrm{Yb}$ & Lu \\
\hline A1H1_117 & $<2$ & 0,512180 & 8 & $-8,9$ & 26,3 & 55,6 & 6,3 & 23,1 & 4,2 & 3,6 & 0,5 & 3,2 & 0,7 & 2,0 & 2,2 & 0,3 \\
\hline A1H2_119 & $<2$ & 0,512437 & 6 & $-3,9$ & & & & & & & & & & & & \\
\hline A7H6_119 & $<2$ & 0,512142 & 6 & $-9,7$ & 26,7 & 56,5 & 6,5 & 23,1 & 4,0 & 3,2 & 0,5 & 3,0 & 0,6 & 1,9 & 2,2 & 0,3 \\
\hline A7H6_70 & $<2$ & 0,512132 & 5 & $-9,9$ & 28,6 & 60,3 & 6,8 & 24,6 & 4,4 & 3,6 & 0,5 & 3,3 & 0,7 & 2,1 & 2,1 & 0,3 \\
\hline B2H3_119 & $<2$ & 0,512122 & 7 & $-10,1$ & 22,5 & 49,6 & 5,6 & 19,9 & 3,5 & 2,8 & 0,4 & 2,6 & 0,6 & 1,7 & 1,9 & 0,3 \\
\hline B2H4_8 & $<2$ & 0,512120 & 8 & $-10,1$ & 26,4 & 57,8 & 6,4 & 23,0 & 4,1 & 3,4 & 0,5 & 3,0 & 0,6 & 1,9 & 1,9 & 0,3 \\
\hline C10H3_118 & $<2$ & 0,512117 & 6 & $-10,2$ & 21,7 & 48,1 & 5,3 & 19,3 & 3,5 & 3,0 & 0,4 & 2,7 & 0,5 & 1,6 & 1,6 & 0,2 \\
\hline A1H1_117 & $2-30$ & 0,512259 & 8 & $-7,4$ & 26,4 & 59,0 & 6,7 & 25,1 & 4,7 & 4,3 & 0,7 & 4,1 & 0,8 & 2,5 & 2,5 & 0,4 \\
\hline A1H2_119 & $2-30$ & 0,512655 & 5 & 0,3 & 17,0 & 42,9 & 5,1 & 21,0 & 4,7 & 4,8 & 0,8 & 5,1 & 1,1 & 3,3 & 3,5 & 0,5 \\
\hline A7H6_119 & $2-30$ & 0,512140 & 8 & $-9,7$ & 30,6 & 71,1 & 7,8 & 29,0 & 5,3 & 4,4 & 0,7 & 4,1 & 0,8 & 2,4 & 2,4 & 0,3 \\
\hline A7H6_70 & $2-30$ & 0,512154 & 8 & $-9,4$ & 27,0 & 59,2 & 6,7 & 24,6 & 4,5 & 3,8 & 0,6 & 3,5 & 0,7 & 2,1 & 2,1 & 0,3 \\
\hline B2H3_119 & $2-30$ & 0,512095 & 4 & $-10,6$ & 27,7 & 61,9 & 6,9 & 25,0 & 4,4 & 3,7 & 0,5 & 3,4 & 0,7 & 2,0 & 2,1 & 0,3 \\
\hline B2H4_8 & $2-30$ & 0,512112 & 6 & $-10,3$ & 26,9 & 59,9 & 6,6 & 24,1 & 4,4 & 3,7 & 0,6 & 3,4 & 0,7 & 2,0 & 2,0 & 0,3 \\
\hline C10H2_119 & $2-30$ & 0,512094 & 5 & $-10,6$ & 14,0 & 31,9 & 3,6 & 13,6 & 2,5 & 2,2 & 0,3 & 2,0 & 0,4 & 1,2 & 1,2 & 0,2 \\
\hline C10H3_118 & $2-30$ & 0,512134 & 9 & $-9,8$ & 26,9 & 59,8 & 6,6 & 24,2 & 4,4 & 3,9 & 0,6 & 3,5 & 0,7 & 2,1 & 2,0 & 0,3 \\
\hline A1H1_117 & $30-63$ & 0,512648 & 5 & 0,2 & 17,4 & 41,7 & 5,0 & 20,2 & 4,6 & 4,6 & 0,7 & 4,8 & 1,0 & 3,1 & 3,2 & 0,5 \\
\hline A1H2_119 & $30-63$ & 0,512722 & 4 & 1,6 & 16,5 & 42,3 & 5,2 & 21,4 & 4,9 & 5,1 & 0,8 & 5,4 & 1,2 & 3,5 & 3,7 & 0,5 \\
\hline A7H6_119 & $30-63$ & 0,512520 & 4 & $-2,3$ & 27,1 & 68,5 & 7,5 & 26,7 & 5,1 & 4,0 & 0,6 & 3,7 & 0,8 & 2,4 & 2,6 & 0,4 \\
\hline A7H6_70 & $30-63$ & 0,512499 & 5 & $-2,7$ & & & & & & & & & & & & \\
\hline B2H3_119 & $30-63$ & 0,512313 & 6 & $-6,3$ & & & & & & & & & & & & \\
\hline B2H4_8 & $30-63$ & 0,512263 & 9 & $-7,3$ & 14,6 & 31,5 & 3,5 & 13,2 & 2,5 & 2,4 & 0,4 & 2,2 & 0,5 & 1,4 & 1,3 & 0,2 \\
\hline C10H2_119 & $30-63$ & 0,512163 & 7 & $-9,3$ & & & & & & & & & & & & \\
\hline C10H3_118 & $30-63$ & 0,512117 & 8 & $-10,2$ & 15,1 & 32,8 & 3,7 & 14,0 & 2,7 & 2,5 & 0,4 & 2,2 & 0,5 & 1,3 & 1,3 & 0,2 \\
\hline A1H1_117 & $0-63$ & 0,512268 & 7 & $-7,2$ & 24,6 & 54,6 & 6,1 & 23,1 & 4,4 & 4,0 & 0,6 & 3,7 & 0,8 & 2,3 & 2,4 & 0,3 \\
\hline A7H6_70 & $0-63$ & 0,512148 & 8 & $-9,6$ & 26,5 & 57,3 & 6,5 & 23,8 & 4,3 & 3,7 & 0,5 & 3,3 & 0,7 & 2,1 & 2,0 & 0,3 \\
\hline B2H4_8 & $0-63$ & 0,512122 & 9 & $-10,1$ & 23,9 & 52,5 & 5,8 & 21,2 & 3,8 & 3,3 & 0,5 & 2,9 & 0,6 & 1,7 & 1,8 & 0,3 \\
\hline C10H3_118 & $0-63$ & 0,512499 & 5 & $-2,7$ & 23,6 & 52,6 & 5,9 & 21,4 & 4,0 & 3,4 & 0,5 & 3,1 & 0,6 & 1,8 & 1,8 & 0,3 \\
\hline
\end{tabular}


Table 2

\begin{tabular}{|c|c|c|c|c|c|c|c|c|c|c|c|c|c|c|c|c|c|}
\hline sample & age (ka) & $\begin{array}{c}143 \mathrm{Nd} / \\
144 \mathrm{Nd}\end{array}$ & $\begin{array}{c}2 \sigma \\
\left(10^{-6}\right) \\
\end{array}$ & $\varepsilon \mathbf{N d}$ & $(\mathrm{Nd} / \mathrm{Yb}) \mathrm{N}$ & La & $\mathrm{Ce}$ & $\operatorname{Pr}$ & Nd & Sm & Gd & Tb & Dy & Ho & $\mathrm{Er}$ & $\mathbf{Y b}$ & Lu \\
\hline \multicolumn{18}{|c|}{$\overline{0-2 \mu \mathrm{m} \text { size fraction }}$} \\
\hline A1H1_5 & 0,2 & 0,512128 & 7 & $-10,0$ & 0,83 & 44,5 & 39,8 & 4,6 & 16,4 & 2,9 & 2,3 & 0,4 & 2,3 & 0,5 & 1,6 & 1,8 & 0,3 \\
\hline A1H1_117 & 3,7 & 0,512180 & 8 & $-8,8$ & 0,99 & 26,3 & 55,6 & 6,3 & 23,1 & 4,1 & 3,6 & 0,5 & 3,2 & 0,7 & 2,0 & 2,2 & 0,3 \\
\hline A1H3_119 & 11,1 & 0,512186 & 7 & $-8,8$ & 0,91 & 28,0 & 50,4 & 5,7 & 20,4 & 3,6 & 3,1 & 0,5 & 2,9 & 0,6 & 1,9 & 2,1 & 0,3 \\
\hline B2H3_119 & 16,0 & 0,512122 & 7 & $-10,1$ & 0,97 & 22,5 & 49,6 & 5,6 & 19,9 & 3,5 & 2,8 & 0,4 & 2,6 & 0,6 & 1,7 & 1,9 & 0,3 \\
\hline B2H4_8 & 16,7 & 0,512120 & 8 & $-10,0$ & 1,09 & 26,4 & 57,8 & 6,4 & 23,0 & 4,1 & 3,4 & 0,5 & 3,0 & 0,6 & 1,9 & 1,9 & 0,3 \\
\hline A2H6_119 & 28,5 & & & & 0,96 & 26,7 & 56,8 & 6,2 & 22,2 & 3,9 & 2,8 & 0,5 & 3,2 & 0,7 & 2,0 & 2,1 & 0,3 \\
\hline B4H6_119 & 52,3 & 0,512164 & 9 & $-9,2$ & 0,95 & 24,9 & 53,9 & 5,9 & 21,3 & 3,8 & 2,8 & 0,5 & 3,0 & 0,6 & 1,9 & 2,1 & 0,3 \\
\hline B5H3_118 & 63,4 & 0,512166 & 6 & $-9,2$ & 1,03 & 27,4 & 51,4 & 5,7 & 20,5 & 3,7 & 3,1 & 0,5 & 2,8 & 0,6 & 1,7 & 1,8 & 0,3 \\
\hline B5H6_7 & 71,2 & 0,512149 & 7 & $-9,5$ & 0,99 & 22,4 & 44,3 & 4,9 & 17,4 & 3,0 & 2,5 & 0,4 & 2,4 & 0,5 & 1,5 & 1,6 & 0,2 \\
\hline B6H2_119 & 81,9 & 0,512244 & 6 & $-7,7$ & 0,90 & 21,7 & 42,6 & 4,8 & 17,4 & 3,1 & 2,6 & 0,4 & 2,5 & 0,5 & 1,7 & 1,8 & 0,3 \\
\hline C8H1_9 & 93,8 & 0,512221 & 6 & $-8,1$ & 0,95 & 24,2 & 47,4 & 5,4 & 19,8 & 3,5 & 3,0 & 0,5 & 2,8 & 0,6 & 1,8 & 1,9 & 0,3 \\
\hline A7H4_110 & 111,2 & 0,512135 & 5 & $-9,8$ & 0,96 & 25,1 & 48,8 & 5,5 & 19,6 & 3,3 & 2,7 & 0,4 & 2,6 & 0,6 & 1,8 & 1,9 & 0,3 \\
\hline A7H6_70 & 120,8 & 0,512132 & 5 & $-9,9$ & 1,07 & 28,6 & 60,3 & 6,8 & 24,6 & 4,3 & 3,6 & 0,5 & 3,3 & 0,7 & 2,1 & 2,1 & 0,3 \\
\hline A7H6_119 & 122,8 & 0,512142 & 6 & $-9,7$ & 0,99 & 26,7 & 56,5 & 6,5 & 23,1 & 4,0 & 3,2 & 0,5 & 3,0 & 0,6 & 1,9 & 2,2 & 0,3 \\
\hline B8H3_119 & 128,7 & 0,512164 & 6 & $-9,2$ & 0,98 & 18,1 & 34,0 & 3,9 & 13,8 & 2,4 & 2,0 & 0,3 & 1,9 & 0,4 & 1,3 & 1,3 & 0,2 \\
\hline B8H4_119 & 132,9 & 0,512206 & 5 & $-8,4$ & 0,98 & 23,6 & 44,6 & 5,0 & 18,1 & 3,2 & 2,7 & 0,4 & 2,5 & 0,5 & 1,6 & 1,7 & 0,3 \\
\hline B8H6_7 & 138,7 & 0,512322 & 4 & $-6,1$ & 0,98 & 21,0 & 41,8 & 4,8 & 17,4 & 3,2 & 2,7 & 0,4 & 2,5 & 0,5 & 1,6 & 1,6 & 0,2 \\
\hline C10H2_119 & 140,1 & & & & 1,15 & 27,3 & 62,5 & 6,9 & 25,4 & 4,5 & 3,8 & 0,6 & 3,5 & 0,7 & 2,0 & 2,0 & 0,3 \\
\hline C10H3_118 & 142,6 & 0,512117 & 6 & $-9,8$ & 1,10 & 21,7 & 48,1 & 5,3 & 19,3 & 3,4 & 3,0 & 0,4 & 2,7 & 0,5 & 6 & 1,6 & 0,2 \\
\hline B10H3_119 & 162,8 & 0,512127 & 6 & $-10,0$ & 1,00 & 25,0 & 51,3 & 5,7 & 20,2 & 3,6 & 2,9 & 0,4 & 2,7 & 0,6 & 1,8 & 1,9 & 0,3 \\
\hline B10H4_118 & 165,5 & 0,512145 & 6 & $-9,6$ & 0,99 & 24,4 & 48,7 & 5,4 & 19,4 & 3,4 & 2,8 & 0,4 & 2,7 & 0,6 & 1,7 & 1,8 & 0,3 \\
\hline A10H3_8 & 167,3 & 0,512126 & 7 & $-10,0$ & 0,94 & 23,1 & 45,0 & 5,1 & 18,0 & 3,1 & 2,5 & 0,4 & 2,5 & 0,5 & 1,7 & 1,8 & 0,3 \\
\hline A10H3_119 & 169,3 & 0,512191 & 4 & $-8,7$ & & & & & & & & & & & & & \\
\hline B11H2_97 & 178,9 & 0,512180 & 3 & $-8,9$ & 0,98 & 24,2 & 47,4 & 5,4 & 19,1 & 3,3 & 2,7 & 0,4 & 2,6 & 0,6 & 1,7 & 1,8 & 0,3 \\
\hline B11H3_119 & 181,9 & 0,512194 & 5 & $-8,7$ & 1,00 & 26,7 & 56,0 & 6,2 & 22,1 & 3,8 & 3,2 & 0,5 & 2,9 & 0,6 & 1,9 & 2,0 & 0,3 \\
\hline B11H5_9 & 185,3 & 0,512143 & 7 & $-9,7$ & 0,86 & 21,8 & 37,0 & 4,3 & 15,0 & 2,6 & 2,1 & 0,3 & 2,1 & 0,5 & 1,4 & 1,6 & 0,2 \\
\hline B11H6_9 & 192,6 & 0,512163 & 6 & $-9,3$ & 0,98 & 23,3 & 45,3 & 5,1 & 18,4 & 3,2 & 2,6 & 0,4 & 2,5 & 0,5 & 1,7 & 1,7 & 0,3 \\
\hline B11H6_119 & 195,3 & 0,512175 & 7 & $-9,0$ & 0,97 & 25,2 & 49,4 & 5,6 & 20,1 & 3,5 & 2,9 & 0,4 & 2,8 & 0,6 & 1,8 & 1,9 & 0,3 \\
\hline C13H5_9 & 202,6 & 0,512193 & 5 & $-8,7$ & 0,97 & 27,0 & 53,6 & 6,3 & 22,9 & 4,2 & 3,7 & 0,5 & 3,4 & 0,7 & 2,1 & 2,2 & 0,3 \\
\hline C13H5_119 & 205,2 & 0,512200 & 4 & $-8,6$ & 0,94 & 23,6 & 46,2 & 5,3 & 19,2 & 3,5 & 2,9 & 0,4 & 2,8 & 0,6 & 1,8 & 1,9 & 0,3 \\
\hline A12H3_119 & 217,4 & 0,512201 & 7 & $-8,5$ & 0,92 & 21,0 & 39,8 & 4,5 & 16,3 & 2,9 & 2,4 & 0,4 & 2,3 & 0,5 & 1,5 & 1,6 & 0,2 \\
\hline A12H5_118 & 224,0 & 0,512180 & 5 & $-8,9$ & 0,98 & 25,1 & 49,3 & 5,6 & 19,8 & 3,4 & 2,9 & 0,4 & 2,8 & 0,6 & 1,8 & 1,9 & 0,3 \\
\hline B13H7_9 & 234,8 & 0,512205 & 6 & $-8,5$ & 0,97 & 23,7 & 45,5 & 5,2 & 18,6 & 3,2 & 2,7 & 0,4 & 2,5 & 0,5 & 1,6 & 1,8 & 0,3 \\
\hline B16H3_119 & 253,9 & 0,512110 & 6 & $-10,3$ & 0,97 & 24,0 & 47,3 & 5,4 & 19,1 & 3,4 & 2,7 & 0,4 & 2,6 & 0,6 & 1,7 & 1,8 & 0,3 \\
\hline B16H5_119 & 262,5 & 0,512093 & 5 & $-10,6$ & 1,00 & 25,3 & 47,1 & 5,4 & 18,8 & 3,1 & 2,5 & 0,4 & 2,4 & 0,5 & 1,6 & 1,7 & 0,3 \\
\hline C18H5_118 & 272,0 & 0,512149 & 5 & $-9,5$ & 1,03 & 25,4 & 50,6 & 5,8 & 20,6 & 3,6 & 3,0 & 0,4 & 2,8 & 0,6 & 1,8 & 1,8 & 0,3 \\
\hline B17H2_119 & 277,3 & 0,512141 & 5 & $-9,7$ & 1,01 & 25,4 & 49,6 & 5,6 & 20,4 & 3,6 & 3,0 & 0,5 & 2,8 & 0,6 & 1,8 & 1,9 & 0,3 \\
\hline B17H3_118 & 280,4 & 0,512153 & 6 & $-9,5$ & 1,00 & 27,0 & 53,7 & 6,1 & 22,0 & 3,9 & 3,3 & 0,5 & 3,1 & 0,7 & 2,0 & 2,0 & 0,3 \\
\hline B17H4_119 & 280,4 & 0,512192 & 5 & $-8,7$ & 0,94 & 26,1 & 52,1 & 6,0 & 22,2 & 4,1 & 3,7 & 0,6 & 3,4 & 0,7 & 2,1 & 2,2 & 0,3 \\
\hline C19H6_8 & 300,4 & 0,512151 & 5 & $-9,5$ & 1,04 & 26,3 & 53,0 & 6,0 & 22,2 & 4,0 & 3,4 & 0,5 & 3,1 & 0,7 & 1,9 & 2,0 & 0,3 \\
\hline B18H3_119 & 310,3 & 0,512179 & 7 & $-8,9$ & 1,07 & 25,0 & 51,1 & 5,8 & 20,7 & 3,8 & 3,1 & 0,5 & 2,8 & 0,6 & 1,8 & 1,8 & 0,3 \\
\hline B19H1_119 & 334,9 & 0,512146 & 3 & $-9,6$ & 1,07 & 24,2 & 49,7 & 5,6 & 20,1 & 3,6 & 3,0 & 0,5 & 2,7 & 0,6 & 1,7 & 1,7 & 0,2 \\
\hline A2OH2_119 & 359,2 & 0,512092 & 7 & $-10,7$ & 1,10 & 26,5 & 54,5 & 6,1 & 21,8 & 3,9 & 3,1 & 0,5 & 2,9 & 0,6 & 1,8 & 1,8 & 0,3 \\
\hline A2OH4_9 & 364,8 & 0,512122 & 7 & $-10,1$ & 1,05 & 25,2 & 51,6 & 5,8 & 21,1 & 3,9 & 3,2 & 0,5 & 2,9 & 0,6 & 1,8 & 1,8 & 0,3 \\
\hline $\mathrm{A} 2 \mathrm{OH} 5 \_7$ & 369,1 & 0,512124 & 5 & $-10,0$ & 1,04 & 25,1 & 51,6 & 5,8 & 21,2 & 3,8 & 3,2 & 0,5 & 3,0 & 0,6 & 1,8 & 1,9 & 0,3 \\
\hline B2OH3_119 & 374,4 & 0,512126 & 5 & $-10,0$ & & & & & & & & & & & & & \\
\hline B2OH5_8 & 379,9 & 0,512188 & 6 & $-8,8$ & 1,04 & 24,6 & 49,7 & 5,7 & 20,7 & 3,8 & 3,2 & 0,5 & 3,0 & 0,6 & 1,9 & 2,0 & 0,3 \\
\hline
\end{tabular}


Table 2 - continued

\begin{tabular}{|c|c|c|c|c|c|c|c|c|c|c|c|c|c|c|c|c|c|}
\hline sample & age & $\begin{array}{c}143 \mathrm{Nd} / \\
144 \mathrm{Nd}\end{array}$ & $\begin{array}{c}2 \sigma \\
\left(10^{-6}\right) \\
\end{array}$ & $\varepsilon N d$ & $(\mathrm{Nd} / \mathrm{Yb}) \mathrm{N}$ & La & $\mathrm{Ce}$ & $\mathrm{Pr}$ & $\mathbf{N d}$ & Sm & Gd & Tb & Dy & Ho & Er & $\mathrm{Yb}$ & Lu \\
\hline \multicolumn{18}{|c|}{ 30-63 $\mu \mathrm{m}$ size fraction } \\
\hline A1H1_117 & 3,7 & 0,512648 & 5 & 0,3 & 0,58 & 17,4 & 41,7 & 5,0 & 20,2 & 4,5 & 4,6 & 0,7 & 4,8 & 1,0 & 3,1 & 3,2 & 0,5 \\
\hline A1H2_119 & 8,1 & 0,512722 & 4 & $-3,9$ & 0,54 & 16,5 & 42,3 & 5,2 & 21,4 & 4,9 & 5,1 & 0,8 & 5,4 & 1,2 & 3,5 & 3,7 & 0,5 \\
\hline A1H3_119 & 11,1 & 0,512230 & 9 & $-5,6$ & 0,76 & 18,4 & 38,1 & 4,3 & 16,2 & 3,2 & 2,6 & 0,5 & 2,9 & 0,6 & 1,9 & 2,0 & 0,3 \\
\hline B2H3_119 & 16,0 & 0,512313 & 6 & $-6,3$ & & & & & & & & & & & & & \\
\hline B2H4_8 & 16,7 & 0,512263 & 9 & $-7,2$ & 0,90 & 14,6 & 31,5 & 3,5 & 13,2 & 2,5 & 2,4 & 0,4 & 2,2 & 0,5 & 1,4 & 1,3 & 0,2 \\
\hline A2H6_119 & 28,5 & 0,512230 & 9 & $-7,9$ & 0,83 & 14,2 & 28,6 & 3,2 & 12,0 & 2,3 & 1,9 & 0,3 & 2,0 & 0,4 & 1,3 & 1,3 & 0,2 \\
\hline B4H6_119 & 52,3 & 0,512380 & 10 & $-5,0$ & 0,74 & 15,6 & 27,7 & 3,2 & 12,4 & 2,4 & 2,0 & 0,3 & 2,1 & 0,4 & 1,4 & 1,5 & 0,2 \\
\hline B5H3_118 & 63,4 & 0,512460 & 8 & 3,4 & 0,81 & 17,5 & 36,3 & 4,2 & 16,1 & 3,1 & 2,6 & 0,4 & 2,7 & 0,6 & 1,7 & 1,8 & 0,3 \\
\hline B5H6_7 & 71,2 & 0,512500 & 7 & $-2,7$ & 0,73 & 17,6 & 37,8 & 4,4 & 17,0 & 3,5 & 3,0 & 0,5 & 3,2 & 0,7 & 2,0 & 2,2 & 0,3 \\
\hline B6H2_119 & 81,9 & 0,512594 & 9 & $-0,8$ & 0,70 & 20,7 & 45,3 & 5,3 & 20,2 & 4,1 & 3,5 & 0,6 & 3,8 & 0,8 & 2,5 & 2,6 & 0,4 \\
\hline C8H1_9 & 93,8 & 0,512563 & 9 & $-1,4$ & 0,56 & 19,5 & 44,9 & 5,4 & 21,5 & 4,9 & 4,8 & 0,8 & 5,3 & 1,1 & 3,4 & 3,6 & 0,5 \\
\hline A7H4_110 & 111,2 & 0,512107 & 13 & $-10,3$ & 0,99 & 26,0 & 35,5 & 4,1 & 15,7 & 2,8 & 2,3 & 0,4 & 2,3 & 0,5 & 1,4 & 1,5 & 0,2 \\
\hline A7H6_70 & 120,8 & 0,512499 & 5 & $-2,7$ & & & & & & & & & & & & & \\
\hline A7H6_119 & 122,8 & 0,512520 & 4 & $-2,3$ & 0,95 & 27,1 & 68,5 & 7,5 & 26,7 & 4,7 & 4,0 & 0,6 & 3,7 & 0,8 & 2,4 & 2,6 & 0,4 \\
\hline B8H3_119 & 128,7 & 0,512508 & 7 & $-2,5$ & 0,85 & 16,9 & 36,6 & 4,3 & 16,7 & 3,3 & 2,9 & 0,5 & 2,9 & 0,6 & 1,8 & 1,8 & 0,3 \\
\hline B8H4_119 & 132,9 & 0,512500 & 6 & $-8,8$ & 0,88 & 14,2 & 30,8 & 3,7 & 14,1 & 2,8 & 2,3 & 0,4 & 2,3 & 0,5 & 1,4 & 1,5 & 0,2 \\
\hline C1OH3_118 & 142,6 & 0,512117 & 8 & $-9,3$ & 1,01 & 15,1 & 32,8 & 3,7 & 14,0 & 2,7 & 2,5 & 0,4 & 2,2 & 0,5 & 1,3 & 1,3 & 0,2 \\
\hline B10H3_119 & 162,8 & 0,512187 & 9 & $-2,7$ & 0,91 & 12,0 & 27,2 & 3,2 & 12,1 & 2,3 & 1,8 & 0,3 & 1,9 & 0,4 & 1,2 & 1,2 & 0,2 \\
\hline B10H4_118 & 165,5 & 0,512228 & 9 & $-8,0$ & 0,82 & 12,3 & 27,3 & 3,2 & 11,9 & 2,2 & 1,8 & 0,3 & 2,0 & 0,4 & 1,3 & 1,3 & 0,2 \\
\hline A10H3_8 & 167,3 & 0,512173 & 7 & $-9,0$ & 0,89 & 20,1 & 44,4 & 5,0 & 18,4 & 3,3 & 2,4 & 0,4 & 2,8 & 0,6 & 1,8 & 1,9 & 0,3 \\
\hline A10H3_119 & 169,3 & 0,512432 & 5 & $-4,0$ & 0,66 & 14,1 & 33,4 & 4,0 & 15,6 & 3,2 & 2,9 & 0,5 & 3,2 & 0,7 & 2,1 & 2,2 & 0,3 \\
\hline B11H2_97 & 178,9 & 0,512314 & 8 & $-6,3$ & 0,78 & 12,1 & 27,0 & 3,1 & 12,0 & 2,4 & 2,0 & 0,3 & 2,2 & 0,5 & 1,3 & 1,4 & 0,2 \\
\hline B11H3_119 & 181,9 & 0,512270 & 7 & $-7,1$ & 0,81 & 14,7 & 33,0 & 3,8 & 14,5 & 2,9 & 2,3 & 0,4 & 2,5 & 0,5 & 1,6 & 1,6 & 0,2 \\
\hline B11H5_9 & 185,3 & 0,512184 & 8 & $-8,8$ & 0,80 & 11,6 & 26,1 & 3,1 & 11,4 & 2,2 & 1,8 & 0,3 & 2,0 & 0,4 & 1,3 & 1,3 & 0,2 \\
\hline B11H6_9 & 192,6 & 0,512258 & 11 & $-7,4$ & 0,82 & 15,1 & 34,9 & 4,0 & 15,2 & 2,9 & 2,4 & 0,4 & 2,6 & 0,5 & 1,6 & 1,7 & 0,3 \\
\hline B11H6_119 & 195,3 & 0,512317 & 8 & $-6,2$ & 0,76 & 15,0 & 34,4 & 4,0 & 15,1 & 3,0 & 2,5 & 0,4 & 2,8 & 0,6 & 1,8 & 1,8 & 0,3 \\
\hline C13H5_9 & 202,6 & 0,512500 & 9 & $-7,7$ & 0,57 & 15,0 & 37,1 & 4,4 & 17,3 & 3,8 & 3,6 & 0,6 & 4,1 & 0,9 & 2,7 & 2,8 & 0,4 \\
\hline C13H5_119 & 205,2 & 0,512652 & 5 & 0,3 & 0,49 & 13,6 & 34,7 & 4,2 & 17,3 & 4,0 & 4,0 & 0,7 & 4,6 & 1,0 & 3,1 & 3,2 & 0,5 \\
\hline A12H3_119 & 217,4 & 0,512464 & 9 & $-3,4$ & 0,65 & 12,9 & 29,6 & 3,4 & 12,9 & 2,6 & 2,2 & 0,4 & 2,6 & 0,6 & 1,7 & 1,8 & 0,3 \\
\hline A12H5_118 & 224,0 & 0,512264 & 8 & $-7,3$ & 0,83 & 13,9 & 31,1 & 3,5 & 12,8 & 2,4 & 1,9 & 0,3 & 2,1 & 0,4 & 1,3 & 1,4 & 0,2 \\
\hline B13H7_9 & 234,8 & 0,512478 & 8 & $-3,1$ & 0,71 & 16,3 & 37,4 & 4,0 & 14,3 & 2,6 & 2,1 & 0,4 & 2,4 & 0,5 & 1,6 & 1,9 & 0,3 \\
\hline B16H5_119 & 262,5 & 0,512114 & 6 & $-10,2$ & 0,90 & 14,9 & 32,3 & 3,7 & 13,6 & 2,5 & 1,9 & 0,3 & 2,1 & 0,4 & 1,4 & 1,4 & 0,2 \\
\hline C18H5_118 & 272,0 & 0,512353 & 7 & $-5,5$ & 0,86 & 17,5 & 40,5 & 4,7 & 17,6 & 3,4 & 2,7 & 0,5 & 2,9 & 0,6 & 1,8 & 1,9 & 0,3 \\
\hline B17H2_119 & 277,3 & 0,512194 & 8 & $-8,6$ & 0,92 & 20,6 & 42,4 & 4,8 & 17,6 & 3,2 & 2,6 & 0,4 & 2,7 & 0,6 & 1,8 & 1,8 & 0,3 \\
\hline B17H3_118 & 280,4 & 0,512235 & 5 & $-7,8$ & 0,89 & 19,4 & 43,7 & 5,0 & 18,2 & 3,4 & 2,6 & 0,5 & 2,8 & 0,6 & 1,8 & 1,9 & 0,3 \\
\hline C19H6_8 & 300,4 & 0,512281 & 6 & $-6,9$ & 0,86 & 17,3 & 38,1 & 4,3 & 15,9 & 3,0 & 2,4 & 0,4 & 2,6 & 0,6 & 1,7 & 1,7 & 0,3 \\
\hline B18H3_119 & 310,3 & 0,512395 & 7 & $-4,7$ & 0,66 & 15,5 & 36,0 & 4,2 & 15,7 & 3,2 & 2,7 & 0,5 & 3,0 & 0,7 & 2,0 & 2,2 & 0,3 \\
\hline B18H4_119 & 314,7 & & 0 & & 0,83 & 16,5 & 37,1 & 4,3 & 16,1 & 3,1 & 2,6 & 0,4 & 2,7 & 0,6 & 1,7 & 1,8 & 0,3 \\
\hline B19H1_119 & 334,9 & 0,512263 & 7 & $-7,3$ & 0,86 & 15,3 & 34,9 & 4,0 & 14,9 & 2,9 & 2,3 & 0,4 & 2,4 & 0,5 & 1,6 & 1,6 & 0,2 \\
\hline A2OH2_119 & 359,2 & 0,512111 & 7 & $-10,2$ & 1,08 & 17,3 & 37,6 & 4,3 & 15,4 & 2,9 & 2,2 & 0,4 & 2,2 & 0,5 & 1,3 & 1,3 & 0,2 \\
\hline A2OH4_9 & 364,8 & 0,512148 & 8 & $-9,5$ & 0,96 & 18,5 & 40,0 & 4,5 & 16,7 & 3,1 & 2,5 & 0,4 & 2,7 & 0,6 & 1,7 & 1,6 & 0,2 \\
\hline $\mathrm{A} 2 \mathrm{OH} 5 \_7$ & 369,1 & 0,512149 & 6 & $-9,5$ & 0,95 & 20,4 & 45,6 & 5,1 & 19,1 & 3,6 & 2,6 & 0,5 & 2,8 & 0,6 & 1,8 & 1,9 & 0,3 \\
\hline $\mathrm{A} 2 \mathrm{OH} 5 \_8$ & 369,2 & 0,512203 & 8 & $-9,5$ & 0,93 & 18,6 & 41,7 & 4,7 & 17,4 & 3,3 & 2,6 & 0,4 & 2,7 & 0,6 & 1,7 & 1,7 & 0,3 \\
\hline B2OH3_119 & 374,4 & 0,512218 & 6 & $-8,2$ & 0,78 & 15,1 & 33,2 & 3,8 & 14,2 & 2,7 & 2,1 & 0,4 & 2,4 & 0,5 & 1,6 & 1,7 & 0,2 \\
\hline
\end{tabular}




\begin{tabular}{|c|c|c|c|c|c|}
\hline region & $\begin{array}{l}\varepsilon N d \\
(\min )\end{array}$ & $\begin{array}{c}\varepsilon N d \\
(\max )\end{array}$ & sample type & $\begin{array}{c}\text { nombre of } \\
\text { samples }\end{array}$ & references \\
\hline Honchu Hokkaido & 5,0 & 6,0 & not precised & not given & $\begin{array}{l}\text { Mahoney and references } \\
\text { therein, } 2005\end{array}$ \\
\hline Kyushu Shikoku & $-6,0$ & 4,0 & not precised & not given & $\begin{array}{c}\text { Mahoney and references } \\
\text { therein, } 2005\end{array}$ \\
\hline $\begin{array}{c}\text { Southern Japanese } \\
\text { volcanos }\end{array}$ & $-6,0$ & $-4,0$ & volcanos & $>39$ & $\begin{array}{l}\text { Ishizaka and Carlson, 1983, } \\
\text { Chen et al., 1993; Mahoney } \\
\text { and references therein, } 2005\end{array}$ \\
\hline Kagoshima River & 2,0 & 2,0 & river sediment & 1 & this study \\
\hline Taïwan & $-15,0$ & $-10,0$ & not precised & 55 & $\begin{array}{c}\text { Chen et al., } 1990 \text {; John et al., } \\
1990\end{array}$ \\
\hline Yangtze River (mouth) & $-13,0$ & $-10,5$ & river sediment & 18 & $\begin{array}{l}\text { Goldstein et al., } 1984 \text {; Yang et } \\
\text { al., 2007; Bayon et al., } 2015\end{array}$ \\
\hline Yellow River (mouth) & $-12,6$ & $-10,9$ & river sediment & 4 & $\begin{array}{l}\text { Goldstein et al., } 1984 \text {; Yang et } \\
\text { al., 2007; Bayon et al., } 2015\end{array}$ \\
\hline $\begin{array}{l}\text { Yellow River (all } \\
\text { reaches) }\end{array}$ & $-13,9$ & $-9,6$ & river sediment & not given & $\begin{array}{c}\text { Hu et al., } 2012 \text { and references } \\
\text { therein }\end{array}$ \\
\hline Korean rivers & $-27,5$ & $-13,1$ & river sediment & 8 & Lan et al., 1995 \\
\hline $\begin{array}{l}\text { Korean cristaline } \\
\text { massif }\end{array}$ & $-33,6$ & $-4,5$ & crystaline massif & 58 & Lan et al., 1995; Lee et al., 2002 \\
\hline North Tianshan & $-6,6$ & $-5,2$ & quaternary loess & $>5$ & $\begin{array}{c}\text { Liu et al., } 1994 \text { and references } \\
\text { therein }\end{array}$ \\
\hline SW Tarim Basin & $-12,8$ & $-9,1$ & quaternary loess & $>11$ & $\begin{array}{c}\text { Liu et al., } 1994 \text { and references } \\
\text { therein }\end{array}$ \\
\hline NE China & $-9,6$ & $-8,5$ & quaternary loess & $>2$ & $\begin{array}{c}\text { Liu et al., } 1994 \text { and references } \\
\text { therein }\end{array}$ \\
\hline Ordos Plateau & $-21,0$ & $-10,0$ & quaternary loess & not given & $\begin{array}{c}\text { Chen et al., 2007; Sun et al., } \\
\text { 2008, Hu et al., } 2012\end{array}$ \\
\hline Central Loes Plateau & $-12,0$ & $-7,0$ & quaternary loess & not given & $\begin{array}{c}\text { Chen et al., 2007; Sun et al., } \\
\text { 2008, Hu et al., } 2012\end{array}$ \\
\hline Nanjing & $-12,2$ & $-10,9$ & quaternary loess & not given & $\begin{array}{c}\text { Liu et al., } 1994 \text { and references } \\
\text { therein }\end{array}$ \\
\hline
\end{tabular}

